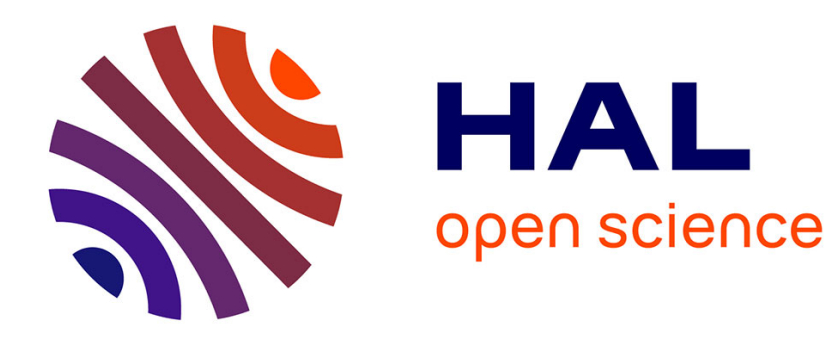

\title{
Friends in cinema. Correspondencias fílmicas: de la subjetividad a la intersubjetividad
}

\author{
Lourdes Monterrubio Ibáñez
}

\section{To cite this version:}

Lourdes Monterrubio Ibáñez. Friends in cinema. Correspondencias fílmicas: de la subjetividad a la intersubjetividad. Área abierta, 2019, 19 (3), pp.439-470. 10.5209/arab.65384 . hal-02611267v2

\section{HAL Id: hal-02611267 \\ https://hal.science/hal-02611267v2}

Submitted on 26 Oct 2021 (v2), last revised 3 Mar 2023 (v3)

HAL is a multi-disciplinary open access archive for the deposit and dissemination of scientific research documents, whether they are published or not. The documents may come from teaching and research institutions in France or abroad, or from public or private research centers.
L'archive ouverte pluridisciplinaire HAL, est destinée au dépôt et à la diffusion de documents scientifiques de niveau recherche, publiés ou non, émanant des établissements d'enseignement et de recherche français ou étrangers, des laboratoires publics ou privés. 


\title{
Área Abierta. Revista de comunicación
} audiovisual y publicitaria ISSN: 2530-7592 / ISSNe: 1578-8393

\section{Friends in cinema. Correspondencias fílmicas: de la subjetividad a la intersubjetividad}

\author{
Lourdes Monterrubio Ibáñez ${ }^{1}$
}

Recibido: 30 de agosto de 2018 / Aceptado: 04 de octubre de 2019

Resumen. El presente artículo analiza la práctica de la correspondencia fílmica a partir del concepto contemporáneo de intersubjetividad: el lugar donde confluyen y se comparten las subjetividades a fin de alcanzar nuevas perspectivas y resultados. El análisis de las correspondencias más relevantes, generadas a lo largo ya de más de tres décadas -desde Video Letter (Tanikawa y Terayama, 1983) a Life May Be (Cousins y Akbari, 2014)-, nos permitirá determinar cómo se produce este desplazamiento de la subjetividad a la intersubjetividad, mediante qué construcciones epistolares, en torno a qué prácticas fílmicas, espacios y temáticas, y con qué resultados. Concluiremos entonces cómo el ensayo intersubjetivo epistolar se materializa en diferentes dinámicas: punto de partida de una reflexión compartida; resultado del intercambio; búsqueda de un espacio creativo; dialéctica entre prácticas fílmicas diferentes; simulacro que aparenta una intersubjetividad que en realidad evita; e incluso su imposibilidad, cuando el intento intersubjetivo amenaza las subjetividades implicadas.

Palabras clave: correspondencia fílmica; cine contemporáneo, subjetividad; intersubjetividad; carta; enunciación

\section{[en] Friends in Cinema. Filmic Correspondences: From Subjectivity to Intersubjectivity}

\begin{abstract}
This article analyses the practice of filmic correspondence based on the contemporary concept of intersubjectivity: the space where subjectivities meet and share in order to reach new perspectives and results. The analysis of the most relevant filmic correspondences, generated over more than three decades already - from Video Letter (Tanikawa and Terayama, 1983) to Life May Be (Cousins and Akbari, 2014) -, will allow to determine how this displacement from subjectivity to intersubjectivity happens, through which epistolary constructions, about which filmic practices, spaces and topics, and with which results. The study will conclude then how the epistolary intersubjective attempt materialises in different dynamics: starting point of a shared reflection; result of the epistolary exchange; search for a creative space; dialectics between different film practices; simulacrum that seems an intersubjectivity that it actually avoids; and even its impossibility, when the intersubjective attempt threatens the subjectivities involved.
\end{abstract}

Key words: filmic correspondence; contemporary cinema; subjectivity; intersubjectivity; letter; enunciation

[fr] Friends in cinema. Les correspondances filmiques : de la subjectivité à l'intersubjectivité

\footnotetext{
1 Universidad Complutense de Madrid (España)

E-mail: loumonte@ucm.es
} 
Résumé. Cet article analyse la pratique de la correspondance filmique à partir du concept contemporain d'intersubjectivité : l'endroit où les subjectivités se rencontrent et se partagent afin d'atteindre de nouvelles perspectives et de nouveaux résultats. L'analyse des correspondances les plus remarquables, générées sur plus de trois décennies - de Video Letter (Tanikawa et Terayama, 1983) à Life May Be (Cousins et Akbari, 2014) -, permettra de déterminer comment se produit ce déplacement de la subjectivité à l'intersubjectivité, à travers quelles constructions épistolaires, autour de quelles pratiques filmiques, espaces et thématiques, et avec quels résultats. On conclura ensuite comment l'essai intersubjectif épistolaire se matérialise dans de différentes dynamiques : point de départ d'une réflexion partagée ; résultat de l'échange ; recherche d'un espace de création ; dialectique entre de différentes pratiques cinématographiques ; simulacre qui semble une intersubjectivité qu'en réalité il évite ; et même son impossibilité, lorsque l'essai intersubjectif menace les subjectivités impliquées.

Mots clé : correspondances filmiques ; cinéma contemporain ; subjectivité ; intersubjectivité ; lettre ; énonciation

Sumario. 1. Introducción. 2. Video Letter (1983) de Shuntarō Tanikawa y Shūji Terayama. La intersubjetividad como herramienta del film-ensayo. 3. Videoletters (1991) de Robert Kramer y Stephen Dwoskin. Intersubjetividad emocional y existencial. 4. This World (1996) de Naomi Kawase y Hirokazu Kore-eda. La intersubjetividad como dialéctica. 5. Correspondencias (2005-2007) de Victor Erice y Abbas Kiarostami. La búsqueda de la intersubjetividad como espacio de creación. 6. In Between Days (2009) de Isaki Lacuesta y Naomi Kawase. De la intersubjetividad y su simulacro. 7. Guerin y Mekas (2009-2011). De la intersubjetividad como imposibilidad y la correspondencia como antítesis. 8. Life May Be (2014) de Mark Cousins y Mania Akbari. La intersubjetividad como resultado. 9. Conclusio-nes. 10. Bibliografía.

Cómo citar. Monterrubio Ibáñez, Lourdes (2019). Friends in cinema. Correspondencias fílmicas: de la subjetividad la intersubjetividad. Área Abierta. Revista de comunicación audiovisual y publicitaria 19 (3), 439-470. https://dx.doi.org/10.5209/arab.65384

\section{Introducción}

La instrumentalización del dispositivo epistolar a lo largo de la historia del cine presenta una apasionante evolución. El cine clásico y su modo de representación institucional hicieron de la misiva un elemento narrativo para proporcionar información que hiciera avanzar el argumento de ficción. Este uso cobró protagonismo hasta convertir la carta en elemento central del relato, siempre vinculado al género cinematográfico que desarrollaba: desde la carta de amor en el drama o la comedia románticos a la carta testimonio que contiene la solución a la intriga en el cine de suspense. La modernidad cinematográfica aportó un nuevo uso del dispositivo epistolar e instrumentalizó la misiva como herramienta para la expresión de la subjetividad, el pensamiento, la imaginación. Surgieron entonces los films-cartas a través de los cuales el autor podía expresar su visión de mundo, siendo Chris Marker y Jean-Luc Godard los dos grandes nombres de esta práctica (Monterrubio, 2018a). Con el advenimiento de la posmodernidad, el concepto de alteridad se convierte en protagónico y el dispositivo epistolar materializa también este cambio de paradigma en la creación audiovisual, dando protagonismo al destinatario epistolar y provocando la evolución del film-carta al film epistolar. Si el film-carta de la modernidad se limitaba a la expresión subjetiva del remitente, el protagonismo de la alteridad hace que el acto epistolar incluya la presencia del destinatario, como ya avanzaba Letter to Jane (Jean-Luc Godard y Jean-Pierre Gorin, 1972) (Monterrubio, 2016). 
En primer lugar, el film-carta se transforma en film epistolar al sustituir la escritura de una única misiva por la lectura de un conjunto de ellas. En el ámbito francófono, dos obras son esenciales en esta evolución. Sans soleil (Chris Marker, 1983) transforma la escritura epistolar hecha film de Lettre de Sibérie (Chris Marker, 1957) en la lectura que de las cartas de Kasna hace la destinataria de las mismas. News from Home (1977) se convierte en film epistolar al construir su enunciación a través de la lectura que de las cartas de su madre hace Chantal Akerman en Nueva York. En segundo lugar, el tú epistolar se convierte en protagonista de la escritura, como ya adelantara Godard, y como confirma Marker con Aleksandr Medvedkin en Le Tombeau d'Alexandre (1993). En tercer lugar, el film epistolar alcanza finalmente a su referencia literaria y la obra se enuncia a través de las cartas de diferentes personas o personajes. Partiendo de esta premisa, el cine contemporáneo genera experiencias fílmicas de gran interés, que se sitúan en la hibridación entre ficción y no ficción, como son Endless Dreams and Water Between (Renée Green, 2009) o Letters from Panduranga (Nguyen Trinh Thi, 2015). Finalmente, se produce un grado más de hidridación y complejización cuando la premisa de la obra es la lectura de una correspondencia epistolar ya existente, como en los casos de The Dreamed Ones (Ruth Beckermann, 2016) o Correspondências (Rita Azevedo, 2016).

Nuestro análisis pretende abordar una práctica concreta de este cine epistolar, la de la correspondencia filmica, definida como el intercambio de misivas audiovisuales, de films-cartas, que pueden dar lugar a un film epistolar, y donde el protagonismo de la alteridad se traslada al concepto de intersubjetividad, ya que se produce la interacción entre autores, el cruce de perspectivas, siguiendo la definición que aporta Isabelle Thomas-Fogiel en su estudio sobre el concepto de intersubjetividad y su protagonismo en la filosofía contemporánea:

Este espacio del nosotros no es la suma del yo y el tú sino el cruce de varias perspectivas, el lugar donde se comparten miradas, el momento de la intersección [...] la intersubjetividad significa pensar esta encrucijada enriquecedora, creando cada vez, mediante la confluencia, la esfera de un nuevo nosotros [...] Pensar la intersubjetividad consistiría, por tanto, en pensar la intersección entre las diferentes perspectivas $[\ldots]$ Yo me dirijo al otro y el otro se dirige a mí, y lo que debe ser estudiado bajo el nombre de intersubjetividad es el cruce de esas intencionalidades. (Thomas-Fogiel, 2014: 384-385)²

No es necesario reincidir en el hecho de que esta práctica audiovisual está totalmente vinculada a la aparición de la tecnología digital y también a la evolución de la misma desde la década de los ochenta hasta la actualidad. Nos disponemos por tanto a recorrer estas creaciones a fin de analizar esta interacción epistolar del gesto cinematográfico, solo al alcance de los friends in cinema, como denomina Jonas Mekas su relación epistolar con José Luis Guerin, y que se cimenta sobre el concepto de fraternidad, como analiza Jordi Balló (2006; 2012; 2014). Además, y como consecuencia de esta fraternidad artística, las correspondencias fílmicas se han convertido también en cruciales experiencias de la transnacionalidad cinematográfica contemporánea, traspasando las fronteras de las cinematografías nacionales.

Las traducciones de citas originales son nuestras. 
Con el propósito de analizar con rigor esta intersubjetividad epistolar, es imprescindible diferenciar aquí las correspondencias descritas de lo que denominamos envíos, donde las obras intercambiadas no responden a una práctica de intersubjetividad epistolar ya que el destinatario no forma parte de la pieza creada. En este sentido, algunas de las correspondencias del proyecto Todas las cartas quedan fuera de la práctica que pretendemos analizar, ya que no se produce un "verdadero diálogo" sino, en el mejor de los casos, "una serie de reflexiones sin un interlocutor" (Balló y Pintor, 2014: 39). Nos referimos a los intercambios entre Albert Serra y Lisandro Alonso, Jaime Rosales y Wang Bin, y Fernando Eimbcke y So Yong Kim. De igual manera, excluimos de nuestro estudio las obras que utilizan el dispositivo epistolar como modo enunciativo a fin de reunir el trabajo de varios autores en torno a una temática, como es el caso de Fluid Boundaries (Daniel Rudi Haryanto, Jeong-hyun Mun y Vladimir Todorovic, 2015), pero que de nuevo no responden a una interacción propiamente epistolar.

El trabajo intersubjetivo apela entonces de manera inevitable a los conceptos de sinceridad y vulnerabilidad, ya que implica "someter a la inteligencia de otra persona las emociones, dudas y creencias propias para acceder a un ejercicio lleno de riesgos, donde lo que a veces está en juego son las propias certezas" (Arroyo, 2011: 247). Solo a través de esa exposición es posible acceder a la subjetividad del otro para hacerla, en algún grado y forma, propia: "El buen escritor de cartas, el buen corresponsal, alcanza sus mejores cotas en la exploración de las posibilidades del tú" (Pintor, 2011: 59). Nuestro estudio pretende realizar un primer análisis acerca de cómo se produce este desplazamiento de la subjetividad a la intersubjetividad, mediante qué construcciones epistolares, en torno a qué prácticas fílmicas, espacios y temáticas, y con qué resultados. Para ello, realizaremos un recorrido cronológico por las obras más significativas de esta escasa, exigente y arriesgada práctica audiovisual, realizadas a lo largo ya de más de tres décadas. Desde la primera obra así identificada, Video Letter (Shuntarō Tanikawa y Shūji Terayama, 1983) a una de las correspondencias más recientes y que creemos más destacada, Life May Be (Mark Cousins y Mania Akbari, 2014), como muestra de la perceptible, aunque tímida, proliferación de esta práctica epistolar en los últimos años.

\section{Video Letter (1983) de Shuntarō Tanikawa y Shūji Terayama. La intersubjetividad como herramienta del film-ensayo}

La materialización de la primera correspondencia fílmica conocida, la creada por Shūji Terayama y Shuntarō Tanikawa entre septiembre de 1982 y junio de 1983 coincide en el tiempo con la creación de Sans soleil, confirmando así la evolución del film-carta de la modernidad al film epistolar de la posmodernidad. Según lo expuesto por Barbara London, ambos autores son incitados a crear una videocarta, que se proyecta desde el inicio como una única obra conjunta:

Con el impulso del Image Forum y de Asahi Publishing, Tanikawa and Terayama comenzaron su intercambio en video. Tanikawa trabajó solo con su equipo de video casero. Terayama utilizó un equipo prestado operado por un ayudante. Su principio fundamental no era editar sus cartas individuales, sino componerlas di- 
rectamente, de forma intuitiva, prestando atención a la velocidad y el flujo de sus ideas en desarrollo. Como una suerte de conversación en la que la espontaneidad es fundamental... (1990: 196)

El film epistolar construido a través de la correspondencia fílmica es posible entonces gracias a dos factores: el trabajo conjunto de dos autores que se conocen en profundidad y la intervención de un mediador que impulsa la colaboración artística. La muerte de Terayama pondrá fin a la correspondencia y el montaje de la obra correrá a cargo de Tanikawa, quien crea un film constituido por dieciséis misivas, respetando la alternancia epistolar. Los cineastas generan entonces un filmensayo que, a través de la intersubjetividad, reflexiona sobre las dialécticas sentidosinsentido e ipseidad-alteridad, esta última propia de la posmodernidad, problematizando las identidades intermitentes de remitente/destinario y ofreciendo ya una de los máximos ejemplos de esta intersubjetividad fílmica: "la confusión de las identidades supone una interrogación, a la vez esencial, lancinante y muy simple, sobre la no identidad subjetiva [...] Así, dirigiéndose al otro, cada uno se interroga sobre la identidad del otro para definir -o para indefinir- la suya" (Bellour, 2009: 262-264).

Cada misiva avanza en una disertación que se construye mediante la forma audiovisual. El pensamiento intersticial (Rascaroli, 2017) y paratáxico (Català, 2014) se materializa en frases-imagen, utilizando el concepto de Jacques Rancière: "La frase no es lo decible, la imagen no es lo visible. Frase-imagen es para mí la unión de dos funciones que deben ser definidas estéticamente, es decir, a partir del modo en que deshacen el vínculo representativo del texto a la imagen" (2011: 64). En este sentido, las voces de ambos cineastas parecen ocupar un espacio mental donde se encontrarían la voz in y off, haciéndolas indiscernibles ${ }^{3}$.

El enfoque/desenfoque de la imagen se instrumentaliza en las dos primeras cartas para reflexionar acerca de la excesiva nitidez del lenguaje, primero: "Al expresarlo en palabras, todo parece un poco demasiado nítido, ¿no crees?”, y sobre la necesidad del mismo después: "Pero algunas veces hay cosas que no puedo soportar sin expresarlas en palabras". La frase-imagen profundiza en la cuestión expuesta ofreciendo una materialización audiovisual del pensamiento. La tercera misiva avanza en esta problematización del sentido mediante la presentación de una imagen abstracta que materializa de nuevo la ambigüedad del lenguaje, incluso su ininteligibilidad, al escuchar sobre ella idiomas desconocidos. En la cuarta, una fotografía rasgada y cosida, primero, y otra cuyos fragmentos se separan, después, profundizan en el argumento que desea expresarse: "Solo el significado puede revivir lo que ocurre por debajo, lo que se desmorona". La reflexión sobre el sentido continúa y en la octava carta Terayama muestra una conversación telefónica entre ambos, acompañada de imágenes que no aportan significación a las palabras, evidenciando así las ventajas de la correspondencia fílmica frente al mero diálogo. La intersubjetividad del pensamiento filosófico se beneficia tanto del diálogo diferido epistolar, que permite la reflexión ante la exposición del interlocutor, como de la materialización de esa reflexión en pensamiento fílmico. Así, en la novena misiva, el movimiento de una araña a través de su tela se convierte en frase-imagen de un nuevo concepto: “¿Sa-

Utilizamos la clasificación que Michel Chion (2004) hace de la voz en la enunciación fílmica: voz in, voz fuera de campo, voz off, y de las posibilidades del acusmáser en el último caso, ya que esta relación entre voz e imagen es la que consideramos más adecuada y fructífera para analizar la enunciación epistolar. 
bes lo que hay entre el significado y el no significado? Una fachada, una ilusión de significado". La trayectoria de la araña se convierte en imagen del significado, del propósito, hasta que de manera arbitraria esta cambia de dirección, deshace el camino andado, y transforma el sentido en sinsentido. Una vez más, la reflexión halla una mayor profundidad y nitidez al materializarse en pensamiento fílmico. En la décima carta, Terayama convierte "la ilusión de significado" de Tanikawa en "ilusión de no significado". Una elipsis temporal entre los retratos fotográficos de la madre de 1927 y su imagen videográfica actual, de 1983, sirve para invertir el argumento: "No puedo evitar sentir que la vida no es 'significado' o 'no significado', sino la ilusión de no significado. Si, la ilusión de no significado. Y el cuerpo va quedando atrás gradualmente".

En la undécima carta, la reflexión acerca de la dialéctica sentido-sinsentido se desplaza al espacio identitario. De nuevo, Tanikawa genera una frase-imagen que materializa su pensamiento. Desde detrás de la cámara, va lanzando diferentes objetos personales sobre la alfombra, para nombrarlos a continuación: "Esta es mi periódico", "Estas son mis llaves", "Este es mi reloj", etc. Finalmente, muestra una parte de su cuerpo: "Este es mi pie”, antes de lanzar una pregunta: “¿Quién soy?” (Imagen 1). Sobre la pantalla en negro surge una segunda cuestión: “¿Es este mi poema?”. Se trata por tanto de una descomposición de la identidad a través de una descomposición del autorretrato, poético-visual en este caso, que da lugar a la imagen en negro, al vacío del sinsentido. En la duodécima misiva, Terayama hace a su vez su descomposición identitaria: “¿Yo soy esto?”, a partir de la presentación y negación de los objetivos que ofrecen representaciones de su identidad: su nombre escrito, su imagen fotográfica, la grabación de su voz. El autorretrato surge entonces de la ausencia, la de las figuras de sus collages: “¿Soy el hombre invisible? Quizá, no lo sé”. A continuación, las imágenes de diferentes objetos -carnets, tarjetas, cartas, postales- acompañados por el mismo "quizá" continúan este autorretrato de la duda: “Quizá soy japonés”, “Quizá soy poeta”, “Quizá soy hijo único”. Finalmente, todos esos objetos aparecen amontonados sobre el suelo: “¿Yo sería eso? (Imagen 2). Si la primera descomposición del autorretrato (Tanikawa) utiliza la posesión de los objetos materiales, la segunda (Terayama) instrumentaliza los objetos dedicados a la representación de la identidad para negarlos o cuestionarlos.
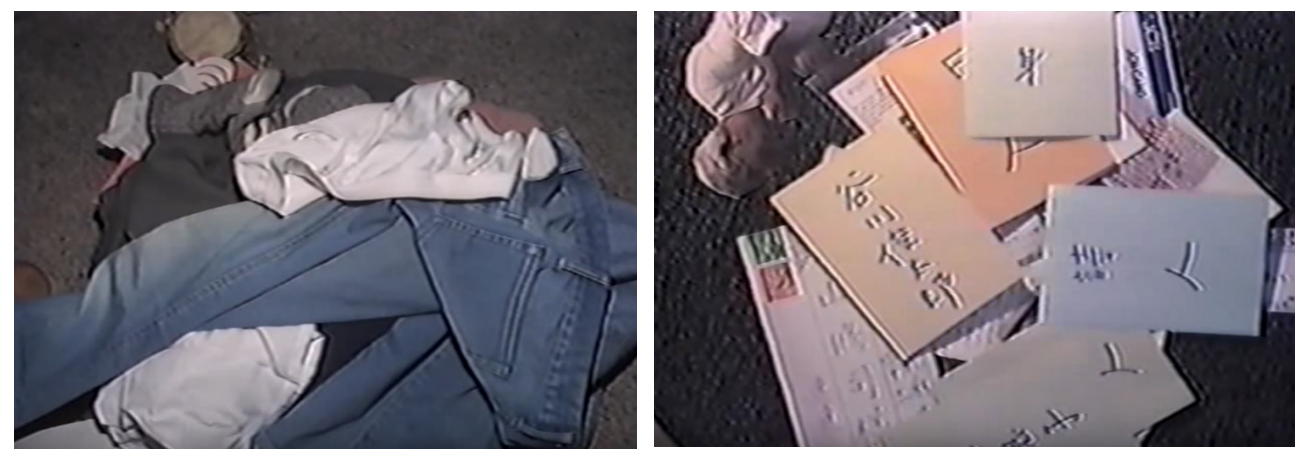

Imagen 1 y 2. Video Letter (Shuntarō Tanikawa y Shūji Terayama, 1983).

Fuente: Captura de pantalla. 
La descomposición del autorretrato de las dos misivas anteriores se completa a continuación con el intento de su pura mostración. En la décimo tercera carta, Taniwaka se coloca frente a la cámara y ofrece su simple retrato, en un único plano, realizando diferentes acciones en silencio. En la décimo cuarta, Terayama avanza un paso más y aborda el retrato del otro. Primero, generando una parodia a través de las respuestas a las preguntas que les plantea a personas anónimas: “¿Qué es Shuntarō Tanikawa?". Después, ofreciendo el verdadero retrato, la obra artística, como confirman los versos del poema "Yo" de Tanikawa, incluidos en Dos billones de años luz de soledad (1952), que Terayama muestra en imagen y sobre los que posa su mano:

Mi vida / un simple cuaderno de notas / una libreta de precio indefinible / (continuidad desde el mundo inorgánico / y espacio en blanco del universo dilatado). / Mi estudiar / lo que escribo en el cuaderno / notas bellas y fervientes sobre ese cuaderno / (no alcanza rigor / y la letra tiende a deformarse) [...] voy caminando / con mi cuaderno de notas / por la senda primitiva del siglo veinte / tok tok tek tek voy caminando / ruborizado voy caminando. (Tanikawa, 2014: 17)

En la penúltima misiva, Tanikawa confirma la tesis del retrato anterior mostrando a Terayama en imágenes pasadas, sin sonido, que alterna con imágenes de máscaras. Sobre una imagen desenfocada que se enfoca paulatinamente, hasta descubrir la figura de Terayama, Taniwaka enuncia: "No puedes aprender quién eres preguntándotelo a ti mismo o preguntándoselo a otro. Ves lo que eres solo en lo que haces".

Tras la muerte de Terayama, Takinawa realiza una última carta de despedida que incide sobre esta identificación entre identidad y obra artística. La línea del electrocardiograma de Terayama, acompañado de su voz recitando uno de sus poemas, se convierte en trazo escritural de su obra poética; la acción que ha dado sentido a su vida, su retrato. El recitado se detiene y el recorrido sobre el cardiograma continúa hasta mostrar la línea plana y detenerse, doble representación de la muerte. A continuación, una panorámica sobre un río concluye con la imagen de un poste sobre el que se sostiene el poema de Terayama. La cámara hace un zoom de acercamiento sobre su conclusión: "Ahora es el momento / con la llegada de mi estación / tímidamente hacia los pájaros / alzo mis brazos / veinte años tengo / en mayo nací".

La obra evidencia cómo la correspondencia fílmica, la intersubjetividad epistolar, se convierte en herramienta principal del film-ensayo. El pensamiento intersticial y paratáxico se genera no solo entre las imágenes y las palabras construidas por cada uno de los corresponsales, sino en las yuxtaposiciones e intersticios que surgen del intercambio epistolar, de la intersubjetividad que se materializa como la constante reconfiguración de la mirada provocada por la interacción epistolar audiovisual.

\section{Videoletters (1991) de Robert Kramer y Stephen Dwoskin. Intersubjetividad emocional y existencial}

El uso de la misiva como dispositivo enunciativo es abundante en la obra de Robert Kramer anterior a la correspondencia mantenida con Dwoskin: Doc's Kingdom (1988), Route One/USA (1989), Dear Doc (1990) o Berlin 10/90 (1991) (Bax, 2006). En lo que respecta a Dwoskin, su cuantioso archivo, en proceso de ordenación y aná- 
lisis ${ }^{4}$, incluye otras correspondencias audiovisuales, al menos, con otros dos interlocutores -Anthea Kennedy (editora y realizadora británica, que aparece en imagen en la segunda de estas misivas) y Dilys Tonge-, mantenidas ese mismo año. Nos hallamos ante la única correspondencia fílmica que no es concebida como un proyecto cinematográfico per se, es decir, que se gesta como una correspondencia privada que posteriormente es recopilada y proyectada por primera vez en 1997. Todas las referencias a esta correspondencia, grabada en Hi8, la describen como compuesta por siete misivas, cuatro de Kramer y tres de Dwoskin, realizadas entre febrero y junio de 1991. La versión a la que hemos tenido acceso, gracias a la inestimable ayuda de Keja Ho Kramer, solo recoge seis, y omite la última misiva de Kramer (5 de junio 1991). Realizamos nuestro análisis siendo conscientes de esta ausencia.

Dwoskin describe con claridad las premisas del proyecto. Por un lado, un ejercicio de despojamiento técnico determinante para la realización de las cuatro primeras misivas, y posteriormente quebrantado en las dos últimas, como analizaremos a continuación: "Las cartas tenían una regla específica cuando comenzamos: no editar" (Dwoskin y Kramer, 2006). Kramer, sin embargo, añade a lo anterior un aspecto de sumo interés: la dialéctica entre esa premisa de la no manipulación y la creación de la puesta en escena que implica la interpretación del remitente (Kramer, 1997). Por otra parte, la correspondencia tiene como objeto una reflexión íntima en torno a un vínculo claro sobre el que trabajar la intersubjetividad: el exilio europeo de dos cineastas americanos nacidos el mismo año, 1939, y en la misma ciudad, Nueva York (Bovier, 2006). Asistimos, por tanto, a una correspondencia que persigue una suerte de grado cero de la escritura epistolar audiovisual, donde la imagen y el sonido, sincrónicos, no se alteran tampoco en montaje, reivindicando su relación con el presente y el flujo de pensamiento espontáneo de los cineastas: "la carta filmada, en su relación ontológica con el presente, adquiere una ventaja evidente sobre la carta escrita" (Bergala, 2011: 28). El firme propósito de intersubjetividad hace que las seis misivas se generen como una suerte de tres dípticos en tono a tres espacios que se convierten en expresiones anímico-existenciales de los cineastas.

Las dos primeras cartas sobre el espacio interior habitado por cada uno de los corresponsales -el apartamento de Kramer durante su estancia en Berlín y a la casa de Dwoskin en Londres- se transforman en expresiones del estado anímico y momento creativo de los cineastas. El desorden mental y la impotencia creativa de ambos se materializa en la geografía de sus espacios y materiales de trabajo. Frente a este caos, Kramer opone una silla solitaria como espacio de reflexión: "La silla en el centro de la habitación es un espacio de meditación [...] Cualquier cosa para encontrar un anclaje", y una bicicleta cuya rueda gira en el aire como metáfora de la necesidad de cambio: "Mi única solución para despegar", "Huir o tomar distancia", "Estar allí, no estar allí". Estos dos elementos se funden en el espacio anímico de Dwoskin para adquirir un significado muy diferente: su silla de ruedas como materialización del aislamiento, como expondrá en su segunda misiva. Kramer relaciona su trabajo creativo con la cultura americana a la que pertenece a través de la cita -primero la lectura de dos pasajes de Luz de agosto (Light in August, 1932) de Faulkner (habrá un tercero en su segunda misiva) y la escucha del poema Howl (1956) de Allen Ginsberg después-. El cineasta comienza a leer, pero al momento se detiene: "Esta

El proyecto The Legacies of Stephen Dwoskin puede consultarse aquí: https://research.reading.ac.uk/hcic/research/the-legacies-of-stephen-dwoskin/ 
música no va bien. Espera". Se levanta, sale de cuadro, apaga la música y vuelve a entrar: "Quería mantener esta música como elemento de continuidad, pero queda un poco raro". Se trata por tanto de un instante de máxima significación donde se revela la inherente puesta en escena de la misiva audiovisual de la que hablaba Kramer, incluyendo su rectificación, como si de una tachadura en el texto se tratara. De la lectura de Faulkner, un pasaje inicial sobre el viaje en carreta de Lena (1983, 8-9), surge la reflexión sobre el viaje asociado al exilio, determinado este por la no pertenencia cultural: "Sí, leo mucho a Faulkner. América. Somos americanos, Steve, lo que quiera que eso signifique. Nuestras obsesiones, nuestra cultura... Quizá lo sea yo más que tú, quizá lo sea mucho más que tú, no lo sé”. Para Dwoskin, sin embargo, la reflexión sobre el exilio en la primera misiva gira en torno al espacio memorístico con el que trabaja: "Las fotografías están llenas de recuerdos. Algunas se remontan lejos en el pasado. Pero no sé si tengo recuerdos de América. Aquí hay uno".

Las segundas misivas, sobre el espacio exterior - la ciudad de Berlín para Kramer y los alrededores de su casa en Brixton para Dwoskin- amplían su carácter existencial. El paseo de Kramer posibilita el tránsito de la reflexión histórica a la existencial, de nuevo en relación al exilio: "Quisiera hablarte de lo nos empuja a hacer una película y no otra. $\mathrm{O}$ de si esta separación de nuestro país, de nuestra cultura, tiene algún significado [...] Déjame mostrarse cómo es ese interior. El interior de la separación". Ese interior metafórico va a ser el de la antigua embajada española en Berlín y las huellas de la II Guerra Mundial en él. Una vez más, la reflexión existencial se convierte en atmósfera. De regreso en el apartamento, Kramer relata un sueño: "Tuve un sueño hace unos días, Steve. Era muy específico... Estaba soñando contigo o para ti, no lo sé. Y por la mañana recordaba fragmentos que me han sido útiles [...] En una habitación oscura o un jardín oscuro el mundo se estaba acabando. Tú decías que no podías reaccionar". La correspondencia genera entonces una actividad onírica que a su vez será fuente de inspiración artística. Kramer concluye la misiva mostrando nuevamente, como en la primera misiva, la silla solitaria, el espacio posible donde meditar (Imagen 3). Dwoskin, sin embargo, va a ofrecer una contundente oposición de lo que representa para él el espacio exterior debido a sus problemas de movilidad: el repetitivo recorrido por la acera que rodea su casa, mostrado a través de travellings grabados desde su silla de ruedas. Un total de siete repeticiones del mismo itinerario, incluyendo la entrada y salida de la casa: "Así es la vida en una silla [...] Este es mi mundo". Entre ellos, una panorámica en la oscuridad del interior parece materializar el sueño relatado por Kramer en su misiva, sin que Dwoskin pronuncia palabra alguna. Otra atmósfera que traduce la situación existencial. Esta misiva exterior, sus repetitivos itinerarios, se convierte así en irrefutable testimonio de su aislamiento, relacionado con el exilio y la no pertenencia: "Este país que no es el mío. Pensaba volver a América, pero no veo ninguna razón para ello. Está tan lejos de aquí. Ya no me sentiría en casa nunca más. Ya no poseo nada, a parte de mi proyecto. Pero este lugar nunca... Esta cultura me es extraña". Como hiciera Kramer, Dwoskin recurre a la cita literaria. Primero un fragmento de su novela $H a$, $H a$ (1993), que se publicará dos años más tarde. Después un fragmento de Los cuadernos de Malte Laurids Brigge (Die Aufzeichnungen des Malte Laurids Brigge, 1910), única novela de Rilke, que sintetiza la experiencia de soledad de Dwoskin: "Pues ahora sabía que allí todo continuaba con la misma indiferencia y que tampoco fuera existía nada distinto de mi soledad. La soledad que yo había hecho a mi alrededor, y cuya grandeza no estaba ya en proporción a mi corazón" (Rilke, 2003: 169). 
Las terceras misivas, en las que quebrantan la premisa de la no manipulación, del montaje en cámara, evidencia la necesidad de convertir la correspondencia en experimentación fílmica. Kramer propone una imagen sonora grabada en Paris, que se une a una imagen visual de un entorno natural, el de su casa en Rouen. La imagen sonora recoge la voz de Kramer describiendo el apartamento parisino en el que se halla, y que será su nuevo estudio. Se trata por tanto de una grabación de video de la que se ha omitido la banda de imagen para sustituirla por una imagen visual antónima, la de un entorno natural, que está grabado de la misma forma que imaginamos la imagen visual omitida: cámara en mano y con montaje en cámara. Las imágenes de la orilla del río y la casa antigua se convierten en imagen antitética de la descripción que Kramer hace del apartamento parisino en la imagen sonora. La carta de Dwoskin experimenta igualmente la separación de la imagen visual y la sonora: la digresión verbal de la segunda se acompañada de imágenes que funcionan como retrato atmosférico de lo expuesto en palabras, pero que deben ser grabadas de forma independiente: "Mi cuerpo me da muchos problemas [...] Esa es la razón por la que estoy haciendo el sonido de esta manera. Cuando miro por el visor solo pienso en la imagen que estoy grabando y no en la que pensaba antes de grabar". Además, introduce un nuevo elemento de montaje: el corte de plano, que va acompañado por un efecto de movimiento vertical de la imagen, coincide también con el corte abrupto del sonido. Es decir, la imagen visual y la imagen sonora, que sabemos independientes, se sincronizan sin embargo en el momento del corte, reincidiendo así sobre su vinculo emocional, materializando su atmósfera. Avanzada la misiva, la imagen temblorosa muestra de nuevo la silla de ruedas (Imagen 4) mientras escuchamos la voz de Dwoskin: "He estado con el ánimo raro estos últimos meses, los dos últimos meses. No tengo la impresión de escribir cartas, más bien un diario, de alguna manera". El impulso epistolar parece desvanecerse, la escritura ya no necesita del otro.
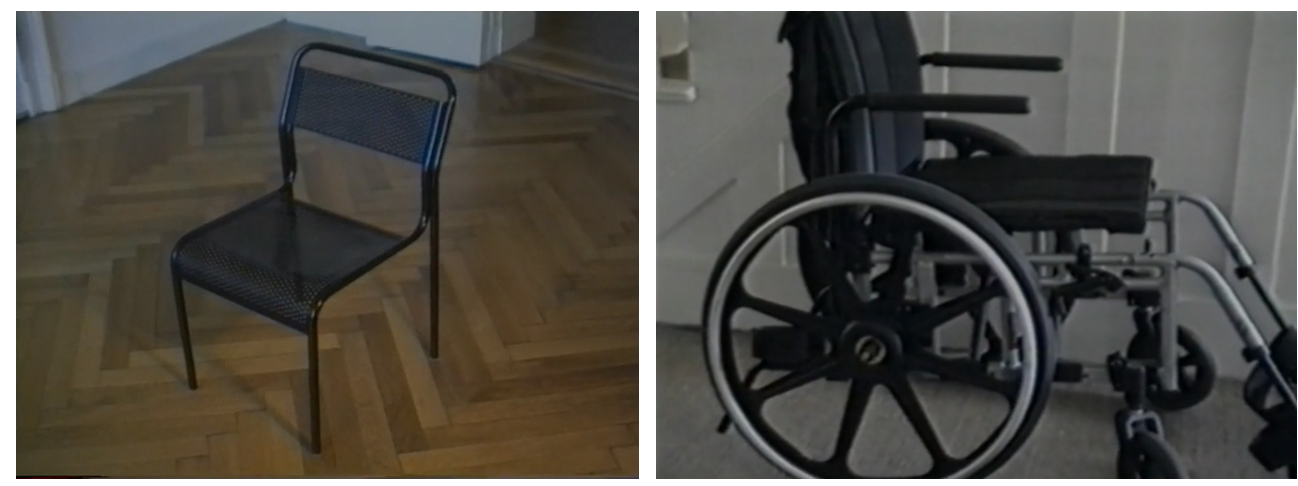

Imagen 3 y 4. Videoletters (Robert Kramer y Stephen Dwoskin, 1991).

Fuente: Captura de pantalla.

Esta correspondencia, y especialmente las cuatro primeras misivas, grado cero de la escritura epistolar audiovisual, permite materializar, captar y compartir las atmósferas anímicas y existenciales de ambos cineastas, gracias a la materialización de la digresión, del flujo de pensamiento espontáneo que se plasma igualmente en la imagen. Las diferentes músicas que escuchan ambos corresponsales también participan de la atmósfera transmitida. Se genera entonces un retrato intersubjetivo, emocional y existencial, en torno a la creación y el exilio. Es preciso añadir aquí que 
esta correspondencia fílmica se convertirá, por primera y única vez, en documento autobiográfico que Dwoskin incluye en su film Trying to Kiss the Moon (1994), frase que utiliza en su tercera misiva con Kramer, e imagen con la que concluye el film. La correspondencia se convierte, junto a las imágenes de la infancia de Dwoskin, en hilo conductor de la película, lo que denota la relevancia de esta correspondencia en su obra. Los fragmentos elegidos son los que expresan con mayor potencia el espacio intersubjetivo del estado anímico y la reflexión existencial.

\section{This World (1996) de Naomi Kawase y Hirokazu Kore-eda. La intersubjetividad como dialéctica}

Naomi Kawase y Hirokazu Kore-eda se conocieron en el Yamagata International Documentary Film Festival en 1995. Allí surge el proyecto de una correspondencia fílmica en $8 \mathrm{~mm}$ que sería exhibida en el Yokohama Museum of Modern Art. Por tanto, frente a las dos correspondencias anteriores, realizadas por experimentados creadores con una relación personal, nos hallamos en este caso ante una correspondencia de dos cineastas en ciernes que no se conocen. Como indica Balló, en estos casos las cartas pueden convertirse en "vehículo para el descubrimiento del otro" (2014: 317). Además, el proyecto se situaba en el territorio creativo de Kawase -la enunciación en primera persona y la filmación en $8 \mathrm{~mm}$ - que a Kore-eda le es totalmente ajeno. This World se compone así de 6 cartas, tres de cada autor, que se desarrollan entre diciembre de 1995 y la llegada de la primavera. Las misivas de Kawase se construyen como cartasemoción mientras que las de Kore-eda abordan la reflexión acerca de su dificultad para situarse en la esfera íntima como punto de partida de la creación artística. Es decir, la intersubjetividad se convierte en una dialéctica entre las materializaciones de Kawase y las reflexiones de Kore-eda sobre cómo acceder a ese espacio.

La primera carta de Kawase delimita la dimensión emocional de la que surgirán sus tres misivas, rechazando cualquier posibilidad de reflexión y casi de narración. El registro sonoro del contestador automático de Kore-eda, con la pantalla en negro, da paso al mensaje audiovisual de la remitente. Sobre una valla metálica convertida en pentagrama musical y ante un cielo soleado (Imagen 5), escuchamos la voz off de la cineasta: "3 de diciembre, tiempo soleado. Es el aniversario de la muerte de mi abuelo. He visitado su tumba". El Himno a la Alegría de Beethoven (1824) se acompaña entonces de tres planos detalle de incienso y flores sobre la tumba, seguidos de varios planos de kakis secos asociados al recuerdo del abuelo. A continuación, un segundo bloque genera una imagen-reflexión, que es una excepción en las misivas de Kawase. Un primer plano, sin sonido ambiente, nos muestra a la cineasta secándose el pelo frente al espejo y dirigiendo después su mirada a la cámara. Es decir, la subjetividad-sujeto se transforma en subjetividad-objeto. La voz off de Kawase, también transformada, impostada y susurrante, usa la imagen sonora para materializar esa misma transformación de la subjetividad: "La toalla que ha lavado mi abuela huele a sol. ¿A qué olería una toalla lavada por Naomi?". Se vinculan así los dos aspectos clave: un ejercicio de intimidad que se convierte en el espacio de exploración de la intersubjetividad epistolar de la obra; y la dualidad identidad-alteridad inherente al individuo y también a la práctica epistolar. A continuación, un tercer bloque genera una imagen-emoción en torno a la infancia: la imagen sonora de un coro infantil y las imágenes visuales de un atardecer y de unos niños jugando. Además, se introduce otra imagen silente. Con la 
cámara en una mano y una tiza en la otra, Naomi escribe sobre el suelo: "Naomi. Educación Primaria". En su conclusión, resurge la voz impostada de Kawase que hemos escuchado anteriormente: "Espero que nos veamos. Quiero verte".

La respuesta de Kore-eda va a retomar los diferentes espacios evocados por Kawase para generar la reflexión. Sobre diferentes planos de una estancia interior escuchamos la voz off del cineasta: "Observar algo, o continuar haciéndolo, es difícil. ¿Significa eso que establecemos una relación con el objeto?’ La filmación se traslada entonces al exterior. Kore-eda filma un escaparate de televisores sobre el que se refleja su imagen: "He hecho un film pero no he establecido una buena relación ni con lo que llamamos una película ni con lo que traté de expresar. No pude capturar la realidad. La vacuidad de mi vida se refleja en mi trabajo. ¿Qué es lo que filmé?’. La sinceridad y la vulnerabilidad de Kore-eda no surge de la intimidad o la emoción sino de la reflexión. Esta continúa mientras las imágenes muestran el paseo por la ciudad en época navideña: "Para mí es más importante mostrar que mirar. Es así como lo siento. Por tanto, esta vez he decidido solo mirar". De nuevo en el interior, el cineasta se filma a sí mismo frente al espejo: "Por primera vez he salido por la ciudad con mi cámara. Con naturalidad, la cámara se ha girado hacia mí. Hacía mi interior, hacia mi memoria". La visita a sus padres por año nuevo le permite filmar su antigua escuela y el tablón de anuncios de la entrada, en correspondencia con la inscripción de la misiva de Kawase. La imagen-emoción de ella se convierte aquí en imagen-documento del lugar presente. Y una vez más, se filma frente a un espejo de la carretera: "El hecho de estar aquí, el sentimiento de estar vinculado a algo; me gustaría filmarlo con realismo". El cineasta continúa con su intento de mostrar un sentimiento de forma realista, al filmar la casa de sus padres. Una nueva imagen va a retomar la misiva de Kawase. Kore-eda muestra un naranjo: "Planté aquí las semillas de una naranja que me comí. Por tanto, este árbol tiene ya quince años. Nunca ha dado flores ni frutos, pero huele a naranjas". A continuación, muestra un anochecer, sin música ni sonido añadido, y el pentagrama musical de Kawase encuentra su materialización realista en el tendido eléctrico de Kore-eda. Un pentagrama que puede abarcar con su mano: "Encontré tu mirada a través de la pantalla. A través del visor, hago de mi memoria esa mirada" (Imagen 6). El autor ofrece así la primera gran definición de la intersubjetividad fílmica que analizamos, en total correspondencia con lo teorizado por Thomas-Fogiel: "Pensar la intersubjetividad como interrelación sería por tanto aceptar el convertirse, en cada instante, en el sujeto de esta pluralidad de perspectivas" (2014: 386-387). El plano asume la subjetividad de su corresponsal para hacerla propia.
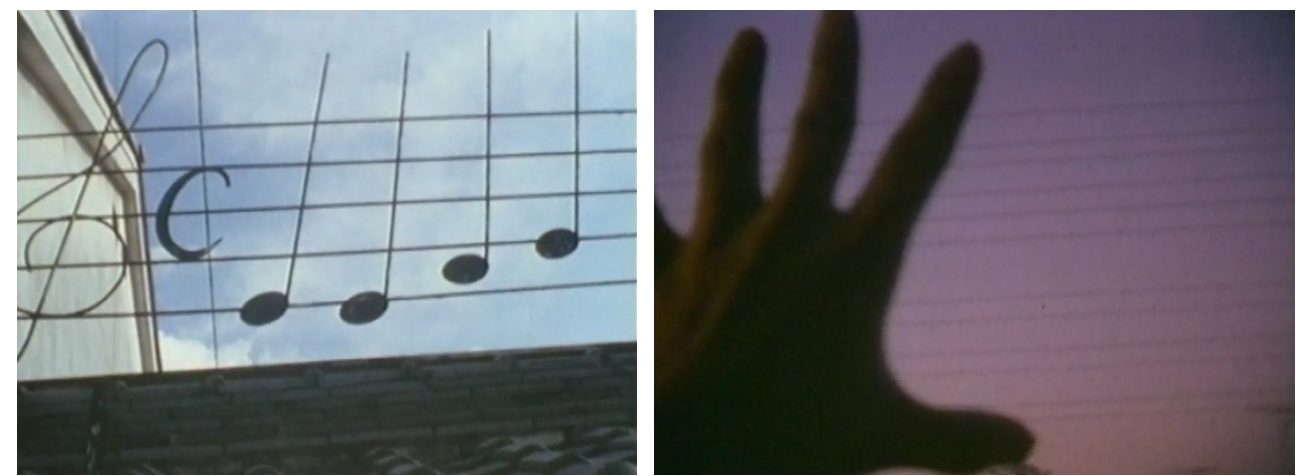

Imagen 5 y 6. This World (Naomi Kawase y Hirokazu Kore-eda, 1996).

Fuente: Captura de pantalla. 
En su segunda misiva, Kawase va a profundizar en la mostración de la intimidad. Su voz deja un mensaje en el contestador de Kore-eda, mientras la imagen, en penumbra, recorre el detalle de unas pinzas suspendidas, metáfora de la vulnerabilidad que muestra la cineasta, llevándola así al espacio intersubjetivo: "Hola, soy Naomi, qué tal estás. Hace casi cuatro meses que nos conocimos en Yamagata. E1 tiempo ha pasado tan rápido... ¿Solo cuatro meses?, ¿o quizá ya cuatro meses?”. A continuación, la misiva retoma la reflexión sobre la acción de mirar (frente al mostrar) de Kore-eda, sobre la que Kawase introduce una vez más la emoción subjetiva que transforma la imagen. Frente a la imagen-documento de una mujer en un cruce, Kawase opone la imagen-emoción de ese mismo espacio urbano, generada a través de su manipulación (ralentización y congelado, ausencia de sonido, alteración del color). De esta forma la cineasta materializa la dialéctica intersubjetiva entre la mirada documental de Kore-eda y su mirada emocional. A continuación, y frente a los diferentes autorretratos que Kore-eda ha incluido en su primera misiva, todos ellos filmados por él mismo en los reflejos de cristales y espejos, cámara en mano, Kawase responde con un autorretrato filmado por otra persona a la que se le confía la cámara y ante la que se actúa de forma espontánea; el despojarse de la cámara para mostrarse frente a ella supone un paso más allá en la exploración íntima. A esta exposición, Kawase añade una suerte de recreación en la misma, con la ralentización de las últimas imágenes antes de concluir la carta con un simple: "Adios". Si Kore-eda desea mirar, Kawase quiere mostrarse, en una tensión constante del espacio de la intersubjetividad.

La segunda misiva de Kore-eda, filmada en Amsterdam, se convierte primero en una reacción ante la tensión expuesta, y dedica su carta a mirar un carromatoorganillo en torno al que se reúnen, juegan y bailan varios niños. De nuevo, el cineasta retoma un motivo de la primera misiva de Kawase (los niños jugando en el parque) para aportar su punto de vista documental, también al retratar a un mimo callejero primero y una pista de patinaje después, donde niños y adultos disfrutan de un tiempo de recreo. Tras esta observación, Kore-eda elimina el sonido ambiente e introduce el de la cámara antes de iniciar su reflexión, su subjetividad en forma de voz off: "Me gusta filmar los sonidos, los colores y la gente con la que me encuentro cuando viajo [...] Quizá porque estas personas son extrañas para mí. Al volver a mi cotidianidad, a veces tengo miedo de filmar". En esta última frase la imagen de un niño en la pista helada corta al entorno habitual de Kore-eda, un parque. La reflexión en off continúa sobre esta nueva imagen: "He descubierto que no tengo ni la habilidad ni la capacidad de observar con detenimiento mi vida y mi entorno de manera realista. No lo consigo, me da miedo. [...] Siento someterte a todo esto, pero por el momento... el hecho de que no pueda filmar es el tema que me gustaría abordar". Toda esta reflexión va a acompañada de un plano dubitativo, cámara en mano, que fluctúa por los elementos de una zona arbolada vacía, transmitiendo esa dificultad.

En su tercera misiva, la cineasta ofrece nuevamente una materialización de lo que Kore-eda expresa como dificultad. En esta ocasión, la imagen inversa a la ofrecida en su misiva anterior; no ella filmada por un ser querido, sino ella filmando en primeros planos a amigos a los que les pide que pronuncien su nombre. Una vez más, Kawase captura la espontaneidad de su entorno íntimo, un espacio de juego y despreocupación, de emociones, totalmente desconectado de reflexión alguna. A continuación, se presenta una serie de planos detalle junto a, de nuevo, la melodía de un coro de niños cantando. El último plano de la correspondencia de Kawase es 
una nueva inscripción de su propia mano, en este caso sobre la ventana cubierta de vaho: "¡He vuelto a casa!"

La última carta de Kore-eda muestra en primer lugar imágenes de un parque y de un grupo de niños jugando en la orilla de una charca. Una vez más, la infancia es motivo recurrente en ambos interlocutores, pero desde puntos de vista muy diferentes. En Kawase se configura como espacio de memoria emocional imprescindible para entender el tono de sus cartas, mientras que en Kore-eda es un elemento de la realidad actual de la que toma registro documental. A continuación, Kore-eda deja la cámara en manos de otra persona para poderse delante de ella y ofrecernos, al fin, su autorretrato completo. Mira a cámara, saluda y habla sin que podamos escuchar sus palabras; se muestra en imagen pero sin sonido. Tras acceder a la vulnerabilidad del retrato delante de la cámara, Kore-eda ofrece, para concluir, unas imágenes del espacio íntimo, de las personas de su entorno, una pareja con un bebé y una niña que juega. Esta vez ofrece también el sonido de esta escena familiar. De este modo, en su última misiva, Kore-eda abandona la reflexión de la voz off y el mirar de sus anteriores misivas para mostrar su espacio íntimo.

\section{Correspondencias (2005-2007) de Victor Erice y Abbas Kiarostami. La búsqueda de la intersubjetividad como espacio de creación}

La correspondencia entre ambos cineastas es ante todo una sincera y conmovedora búsqueda de un espacio creativo común en el que compartir sus percepciones. Además, esta va a ser pública en su desarrollo, no ya como obra unificada que contenga toda la correspondencia, sino como work in progress de cuyo proceso participa el espectador, ya que tendrá acceso al intercambio epistolar en tres momentos distintos de su producción: cuatro cartas en Barcelona (2006), cinco en Madrid (2006) y su totalidad, diez, en Paris (2007). Además, esta correspondencia es la primera de carácter transnacional, inaugurando así una fértil práctica epistolar que se va a convertir en crucial para las futuras correspondencias.

En su primera misiva, que surge de la escritura sobre el papel y va acompañada de la voz off del cineasta, Erice propone una visita al espacio en el que filmara $E l$ sol del membrillo (1992) casi quince años atrás. Son ahora los nietos de Antonio López los que pintan el membrillero, antes de que la lluvia interrumpa su trabajo como también le ocurriera al pintor. El dibujo de Aurora se convierte en regalo para Kiarostami. Este responde a la misiva de Erice con una maravillosa postal de la geografía de una vaca, que se gira al final de la misma para convertirse en papel y poder escribir sobre ella su mensaje, como hiciera Erice al inicio de la suya: "Querido amigo: Escribirte una carta no es fácil [...] He roto dos cartas anteriores”. Kiarostami acepta así el dispositivo epistolar como espacio de intersubjetividad al tiempo que descarta la temática de la revisitación de la propia obra que propone Erice en su primera misiva. Además, el cineasta introduce la posibilidad de la correspondencia de viaje y explicita la complejidad de la tarea a la que ambos se enfrentan.

Erice prosigue en su segunda misiva la búsqueda de ese territorio común. De nuevo la carta fílmica se inicia con la misiva escrita, en esta ocasión ya concluida, acompañada de la postal de Kiarostami, y algunos recuerdos vacunos de la biografía del cineasta: una fotografía de la infancia y una figura de cerámica. Este pequeño detalle se convier- 
te en confirmación tácita de la búsqueda en la que ambos se han comprometido. Erice informa igualmente a su interlocutor de que la presente carta fue iniciada antes de recibir la postal y que aún tiene muchas dudas sobre esta tarea conjunta de exploración. El cineasta sustituye entonces la revisitación de la propia obra por la de su interlocutor, a la que añade la idea del viaje, en este caso a través del visionado de ¿Dónde está la casa de mi amigo? (Khane-ye doust kodjast?, 1987) por los niños de un colegio de Arroyo de la Luz (Cáceres). Manteniendo así la temática de la infancia, ahora con el asombro infantil ante la ficción cinematográfica, que evoca inevitablemente a El espíritu de la colmena (1973). Las reflexiones de los niños tras la proyección abocan a Erice a la misma reflexión que surge de La Morte Rouge (2006): "Hay una verdad que los adultos olvidamos con frecuencia: que los niños no saben de fronteras, que el mundo entero es su casa" (Monterrubio, 2019b).

La respuesta de Kiarostami evidencia que los cineastas han encontrado el espacio intersubjetivo a desarrollar en su correspondencia, la que se aplica a la revisitación y prolongación de la obra cinematográfica del interlocutor. Si Erice ha prolongado la experiencia fílmica de ¿Dónde está la casa de mi amigo? en Arroyo de la Luz, Kiarostami prolonga la narración de El sol del membrillo a partir de un fruto caído del árbol de Madrid que toca el suelo de Irán. El cineasta reproduce un fragmento del film de Erice (primera vez que encontramos este elemento en una correspondencia) para introducir esta ampliación ficcional, a través de un prolongado fundido encadenado característico de la película de su interlocutor. Del membrillo documental de 1992 a esta ficción epistolar de 2005, en la que, ahora sí, el cineasta puede incluir la primera misiva de Erice en la experiencia intersubjetiva: "En nuestra cultura, si la fruta cuelga más allá de las cuatro paredes de un jardín, pertenece a los transeúntes. Aquí aparecen dos chicos de primaria, un poco mayores que los nietos de Antonio López, que están más interesados en comerse el membrillo que en pintarlo, y hacen del membrillo su objetivo". El periplo del membrillo por el río de Irán, acompañado de la melodía de Boogie Woogie (Pinetop Smith, 1928) concluye en las manos de un pastor que lo comparte con su ganado antes de marcharse con él mientras escuchamos ahora Galliard Battaglia (Samuel Scheidt, 1621). El uso de la música insiste en la idea de la construcción de la carta fílmica, como hiciera con la postal en su primer envío.

Erice continúa la creación de Kiarostami en la quinta misiva, prolongando el personaje del pastor iraní para hacer un retrato de José, un pastor segoviano. Retomando nuevamente el elemento del visionado, Erice muestra a José la carta de Kiarostami, y los espectadores asistimos a su visionado tras haber realizado el propio. La experiencia intersubjetiva se traslada entonces al espectador, que puede comparar sus impresiones con las observaciones de José, las cuales revelan una vez más las relaciones entre ficción y no ficción y la presencia del azar en ambos espacios. Con la mirada de José, desconocedor de la forma cinematográfica pero experto en la acción que esta reproduce, Erice prolonga igualmente el tono cómico de la misiva de Kiarostami: "Jobar, pues no es largo el limón”, "Hay que amolarse qué música más bonita se ha puesto", "Pero coño... este pastor lo está haciendo mal, las arrea; y tiene que ir delante, llamándolas". El construido azar del periplo del membrillo se convierte en el azar real de la espontaneidad de José durante el visionado. Sus palabras sintetizan, sin duda, muchas de las disquisiciones teóricas acerca de la hibridación entre ficción y no ficción característica del cine contemporáneo, de la que ambos cineastas fueron determinantes precursores (Monterrubio, 2018b). 
De los encuentros de los cineastas con motivo de la inauguración de la exposición en Barcelona y Madrid surge un nuevo impulso epistolar. Se genera entonces una suerte de segunda parte de la correspondencia, formada por otras cinco cartas, a partir del delicado trazado del espacio intersubjetivo revelado, y que Kiarostami parece describir en la sexta carta, Rain, que se va a convertir en elemento disruptor de la correspondencia al tiempo que en su poética síntesis. La misiva de Kiarostami está fechada el 18 de marzo de 2006, anterior por tanto a la de José, pero es entregada junto a su siguiente y última carta, después de que Erice haya realizado dos misivas posteriores. Esta disrupción evidencia la vinculación de la intersubjetividad a la lectura epistolar, por lo que situamos el análisis de esta carta en ese momento.

Por tanto, Erice inicia también esta segunda parte de la correspondencia. En este caso, utilizando una enunciación de mayor exposición, situándose delante de la cámara, creando su propia puesta en escena. Sentado a una mesa lee un poema de Omar Jayyam, que de nuevo describe el espacio poético que comparten: "De niños asistimos a clases de maestros / luego fuimos maestros y esto nos alegró / qué fue al fin de nosotros, las palabras lo dicen: / brotamos de la tierra y nos arrastró el viento" (1993: 95). Erice cultiva así la mirada de su interlocutor. Inicia entonces la escritura epistolar, pero su contenido no se da a conocer en esta ocasión. Tras una elipsis (de nuevo un fundido encadenado), Erice enrolla la misiva y la introduce en una botella que es arrojada al mar, en el que flota a la deriva como hiciera el membrillo de la segunda misiva de Kiarostami. El cineasta le propone a su corresponsal construir una nueva narración de este gesto epistolar despojado y azaroso: su contenido es desconocido y su destinatario será sustituido por un receptor aleatorio. Ante la falta de respuesta de Kiarostami, Erice realiza una nueva misiva en torno a la espera: "Debo decir que esta carta mía, $A$ la deriva, está escrita desde la experiencia de pasar nueve meses sin recibir respuesta de Abbas" (Balló, 2011: 44-45). No se trata, sin embargo, de la espera del remitente, sino de la de la propia misiva por ser encontrada, leída. Esto implica que Erice abandone por primera vez el yo epistolar para situarse en la narración objetiva sobre el objeto, la carta. El remitente deja de serlo, desaparece de la enunciación, anticipando el fracaso de la correspondencia. Esta misiva puede interpretarse también como metáfora de la esterilidad de un envio que no se sirva de la intersubjetividad, donde la no recepción física simboliza otra carencia más profunda, la ausencia de miradas compartidas, de la mirada intersubjetiva.

Erice recibe entonces las dos cartas restantes de Kiarostami: Rain y Mapa del tesoro. El retraso de más de un año de la primera (fechada en marzo de 2006, entregada en mayo de 2007) dará múltiples sentidos a la espera de su destinatario. La voz de Kiarostami surge de la pantalla en negro, para informar a Erice del viaje iniciado en coche. Tras el fundido de negro la misiva nos muestra la imagen que recoge la cámara a través del parabrisas sobre el que se dibuja la 1luvia: "Tengo la sensación de que estás a mi lado en este viaje [...] Como te he dicho, en este viaje siento la necesidad de ver las cosas a través de tu mirada. Sé que la naturaleza es uno de nuestros puntos de interés comunes. Por eso he pensado de manera espontánea centrar mi videocarta en una mirada sobre la naturaleza". Como hiciese Kore-eda, Kiarostami ofrece así una nueva definición de la intersubjetividad fílmica: "nuestra relación con el otro reconfigura nuestra relación con el objeto" (Thomas-Fogiel, 2014: 362). El cineasta concluye su enunciación para dar paso a una larga serie de imágenes fijas (cerca de setenta) realizadas desde ese mismo punto de vista, a través del dibujo del agua sobre el parabrisas, que se suceden mediante sutiles fundidos encadenados, y 
que están acompañadas por el Concierto para dos violines y orquesta de Mozart. El filtro de la lluvia abstrae los paisajes que observamos a través de él, otorgándoles una calidad pictórica de enorme expresividad (Imagen 7). Las imágenes fijas de la misiva de Kiarostami, su mirada desde el interior de su coche, contienen otras muchas de la obra de Erice: los paisajes rurales de El espíritu de la colmena y El sur (1983).

En la última misiva de Kiarostami, la carta en una botella encuentra al fin a su azaroso receptor, de nuevo atrapada por las redes de unos pescadores. Uno de ellos rompe el continente para acceder al contenido. Persiguen descifrar la carta para saber si se trata de un mapa del tesoro, pero esta es arrastrada por el viento, como indicaba el poema de Jayyam. Surge entonces la voz off de Kiarostami:

Querido Víctor: Me alegro de que el secreto de tu carta no haya sido desvelado por completo. El viento ha soplado a su capricho, hacia donde ha querido. Así que imagino que te devolverá la carta. Quería también hacerte saber que he leído tu carta sin leerla, y como diría el poeta persa: tus palabras brotan de mi corazón, Guardaré para mí el secreto escondido en la botella.

Así, Kiarostami genera de nuevo una expresión emocional de la intersubjetividad experimentada. Y a ella asocia un repliegue de la correspondencia hacia el espacio privado, donde se conserva el contenido de la carta y donde se situaría su continuación: "Te envío mi nueva dirección postal con la esperanza de recibir nuevas postales tuyas".

La última misiva de Erice, Escrito en el agua, pudiera concentrar las respuestas a las dos cartas de Kiarostami. En primer lugar, y de forma explícita, muestra el final del viaje de la misiva, descompuesta en el agua del mar. En segundo lugar, contesta a Rain: el paisaje filtrado por el dibujo de la lluvia sobre el parabrisas se convierte ahora en los restos epistolares filtrados por el agua del mar (Imagen 8). El agua como metáfora, en ambas misivas, del fenómeno de intersubjetivización. Se evidencia así el éxito de la correspondencia como generador de intersubjetividad en relación a la temática de la creación.
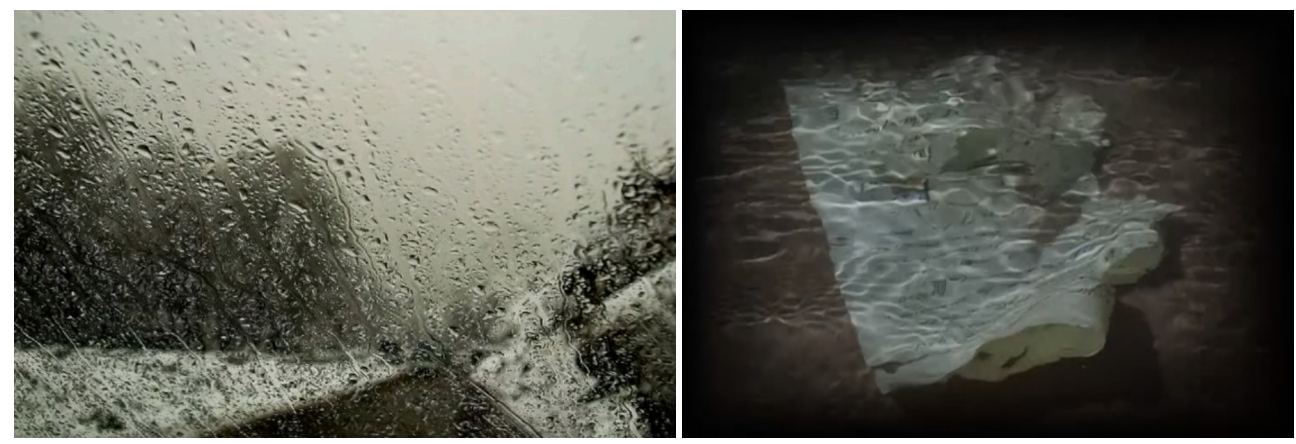

Imágenes 7 y 8. Correspondencias (Víctor Erice y Abbas Kiarostami, 2005-2007). Fuente: Nautilus Films y Centre de Cultura Contemporànea de Barcelona. 


\section{In Between Days (2009) de Isaki Lacuesta y Naomi Kawase. De la intersubjetividad y su simulacro}

En esta segunda correspondencia de Kawase, la premisa inicial se repite: se le propone una correspondencia epistolar con un cineasta con el que solo ha coincidido una vez durante un festival. Por su parte, Lacuesta se sirve de esta propuesta para abordar, por primera vez en su obra, su propia intimidad como espacio cinematográfico. El proyecto se diseña como un intercambio de cuatro misivas (dos de cada autor) que serán presentadas en un encuentro entre ambos (Cinergies, septiembre 2009), donde también se mostrará una filmación conjunta que debe realizarse en los días anteriores al encuentro. Además, los cineastas acuerdan la temática a abordar: su entorno más próximo, tanto físico como humano. Estos acuerdos previos, basados en la expresión subjetiva, anulan en gran medida la búsqueda de la intersubjetividad a la que asistimos en la correspondencia entre Erice y Kiarostami, para transformarla en juego y generar una suerte de simulacro de intersubjetividad, como analizaremos a continuación.

Por primera vez, una correspondencia prescinde de la voz de los corresponsales y se sustituye por el texto escrito sobre la pantalla. Este elemento, de enorme importancia y potencialidad, será instrumentalizado de forma diferente por ambos cineastas. Lacuesta lo utiliza como elemento literario con el que convertir la narración autobiográfica en fábula y simular así una intimidad que en gran medida se evita. Además, el texto sobre la pantalla se vincula con mayor potencia a la ausencia de sonido directo, especialmente en las dos primeras cartas. De este modo, y frente al grado cero de la escritura epistolar audiovisual de Kramer-Dwoskin, encontramos aquí una suerte de misivas literario-visuales. La imagen se transforma en narración epistolar (alejándose de la enunciación), y la súbita aparición del sonido (el del barco en la primera y el de las puertas de los almacenes del museo en la segunda) se configura como expresión de vivacidad de lo fabulado. Kawase, por su parte, hace del texto inscrito sobre la pantalla un uso poético, y lo sitúa en el centro de la imagen para reivindicar su importancia. Así, el texto se define como expresión de la subjetividad, mientras que la imagen, con su sonido directo, pretende captar esa poeticidad de la realidad. Esa misma tendencia se confirma en los formatos de la imagen. Mientras Lacuesta busca su ficcionalización (video B/N y color, fotografía, imágenes de otros autores $\mathrm{y}$ en otros formatos), Kawase mantiene los mismos en el estadio de documento que testimonia esa poeticidad.

En su primera misiva, Lacuesta transforma su presentación y la de su compañera, Isa Campo, en una fábula acerca de un viaje de huida por lugares invisibles. De vuelta a casa, a ese lugar en el que nunca filma, el cineasta convierte de nuevo el retrato de Isa durmiendo en una nueva fabulación sobre una película invisible, mediante unas imágenes en B/N inéditas: "Una vez filmé una película invisible. Nadie la ha visto nunca. Ni siquiera la terminé. De hecho, no es una película, sino un sortilegio para no perderla nunca". La intimidad no se revela sino que se oculta; se protege mediante un filtro fabulador que solo permite vislumbrarla. La misiva de Kawase responde a la fabulación de Lacuesta con la expresión de su espiritualidad. Las imágenes de una oración nocturna, que se suceden mediante fundidos encadenados, se convierten en la oración que Kawase ofrece a su familia y especialmente a su hijo, Mitsuki, quien aparece en imagen en diferentes momentos: 
Hay luz porque hay oscuridad / El tiempo crea luz / Una luz anula otra luz [...]

En mi país siempre se ofrecen oraciones / Su nombre es "luz"

Mi sangre corre por sus venas /

El nombre de su padre es "la gran luz" / Trajeron la luz a mi vida.

En mi país siempre se ofrendan oraciones / No podría existir sin ellos /

Como partícula de este mundo maravilloso / Gracias. Gracias /

¡Os doy las gracias por venir a este mundo!

Como indica Anna Petrus (2011), la misiva da cuenta del cambio de paradigma que se produce en la filmografía de Kawase tras el nacimiento de su hijo, que convierte la oscuridad de la ausencia materna y paterna en la luz de una familia propia y presente. Sin embargo, en lo que al espacio intersubjetivo se refiere, la pieza de Kawase no se vincula al destinatario en ningún sentido. Como indicábamos en la introducción, nos hallamos ante un envío que simula la carta, pero que no apela al tú epistolar.

En su segunda misiva, Lacuesta aborda su infancia a través del relato de la historia del Museo Darder de Banyoles, para convertirlo en una suerte de espacio mítico infantil del descubriendo del mundo: "De hecho, aquí fue donde vi por primera vez un japonés". Una segunda fábula sobre un aviador de la guerra civil le permite retomar su relación de pareja, a través de imágenes fijas suyas en el lago, para asociarlas ahora a la imagen mítica de este, construida con las imágenes de Segundo de Chomón, Gérone, la Venise espagnole (1912) con las que inicia y concluye la carta. De nuevo lo íntimo se transforma en fábula; parece mostrarse, pero en realidad se oculta. La respuesta de Kawase es la actualización de su última misiva en la correspondencia con Kore-eda. Si entonces sus jóvenes amigos pronunciaban su nombre frente a la cámara, ahora lo hace el entorno actual de la cineasta: los trabajadores de su productora y los miembros de su familia. Surge así una materialización emocional de lo conseguido en doce años, de las relaciones construidas, a las que Kawase les pide el mismo gesto, que miren a cámara, pronuncien su nombre y añadan lo que deseen. Esa demanda al otro persiste y Kawase la plasma en el texto: "Estoy aquí, rodeada de mis amigos. A medianoche, estoy aquí, sola. Está lloviendo ¿Dónde estás?” Un montaje encadenado de todos los rostros mostrados sirve de respuesta: "Estoy aquí". De nuevo, el envío de Kawase es una interesante expresión subjetiva e íntima que en ningún momento aborda la intersubjetividad.

Con estas cuatro misivas, los cineastas han concluido la correspondencia y se reúnen solo unos días después para su presentación ante el público y la filmación de una última carta conjunta. Esta finalmente se realiza en $16 \mathrm{~mm}$ (Kawase había propuesto el formato de $8 \mathrm{~mm}$ ), en el lago de Banyoles, pero un error técnico hace que todo el material quede velado. Es esta circunstancia imprevista la que provoca de forma espontánea la prolongación de la correspondencia y la que permite que la intersubjetividad pueda irrumpir finalmente en ella, fortalecida además por la experiencia compartida: "el corazón de la correspondencia entre Lacuesta y Kawase es el que, en la quinta misiva, les permite enfrentarse al vacío de un giro inesperado" (Balló y Pintor, 2014: 45).

La nueva misiva de Lacuesta se materializa a partir de esas imágenes veladas. La carta se inicia con imágenes fijas de esa jornada en el lago, primero pixeladas y después mostradas sin ese efecto, sobre las que el texto, ahora, se sitúa en el centro de la imagen, como en las cartas de Kawase: "Querida Naomi: Ya he recibido la película 
que rodamos cuando viniste a Banyoles. ¡Todo está mal expuesto! Intento distinguir tus tomas de las mías. Por primera vez, me temo que tenemos estilos casi iguales". Por primera vez, Lacuesta aborda así el espacio fílmico intersubjetivo, aludiendo a la similitud de estilo. A continuación, la carta se convierte en un poema visual musicado. La composición de Pascal Comelade, Sense el Ressò del Dring (2002), adaptación del poema de Joan Salvat Papasseit, interpretada junto a Enric Casassses, acompaña a las imágenes veladas sobre la que Lauesta vierte su fabulación, aplicada ahora al espacio intersubjetivo: ¿qué esconden las imágenes veladas? El relato literario de las misivas anteriores se convierte en una suerte de juego infantil, aludiendo a la figura de Mitsuki: "Un lago. Tu hijo corriendo alrededor del lago o un tigre rayado [...] Diego, persiguiendo un león [...] Una nube con la forma de hipopótamo. Nubes que parecen jirafas en llamas" (Imagen 9).

La misiva de Kawase responde entonces a la búsqueda intersubjetiva de Lacuesta, y frente a lo que él fabula sobre las imágenes de aquel día, Kawase ofrece "lo que él recuerda": la experiencia infantil de su hijo de esa jornada, en una suerte de collage, compuesto por las fotos realizadas por el niño, las que toma su madre, y la imagen en movimiento del lago. Un ejercicio de intersubjetividad también entre madre e hijo (Imagen 10). Frente a las experiencias humanas detenidas en el tiempo (imágenes fijas), Kawase opone la imagen en movimiento del lago. Así, retoma su importancia en el imaginario de Lacuesta, actualizando las imágenes de Chomón, para perpetuarlo quizá en la imaginación de su hijo. Además, el recuerdo también es musicado, revelando otro punto de contacto entre los cineastas. La canción elegida por Kawase es Sanpo (2009) de Pascals, grupo japonés cuyo nombre muestra su admiración por Pascal Comelade. Sobre la pantalla en negro final, es la voz de Mitsuki, por primera vez una voz epistolar, la que se despide: "Buenas noches, hasta luego". Una prueba más de la intersubjetividad alcanzada.

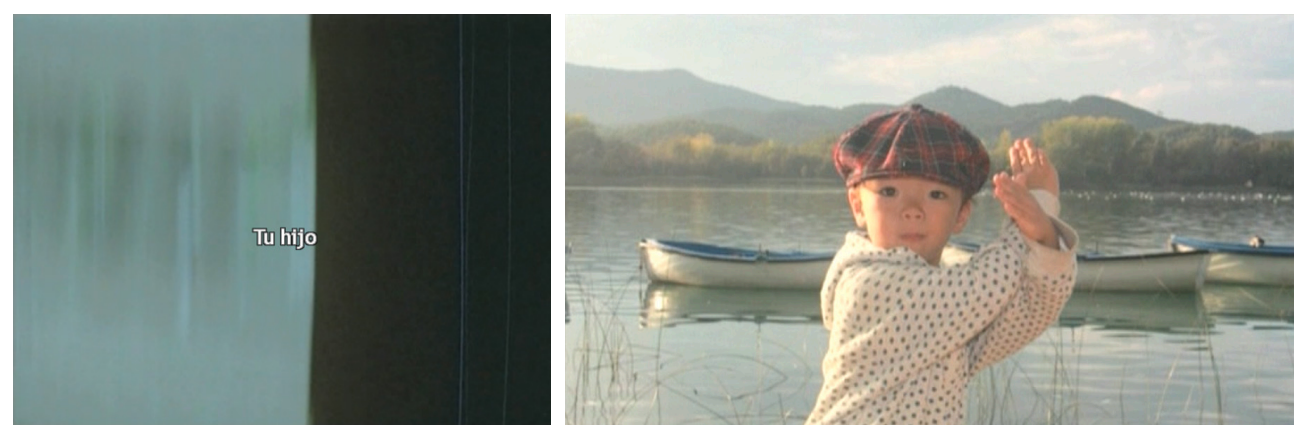

Imágenes 9 y 10. In Between Days (Isaki Lacuesta y Naomi Kawase, 2009). Fuente: Captura de pantalla.

La postdata final de Lacuesta es de nuevo una magnífica materialización de la intersubjetividad, totalmente liberada ya de cualquier premisa. El cineasta le envía unas imágenes tomadas en Mali, donde prepara Los pasos dobles (2011). El cineasta abandona cualquier fabulación para realizar el ejercicio propio de Kawase, la simple captación de un gesto de la realidad que encierra todo un universo poético: "Hoy ha llovido, la primera lluvia de la temporada. Y quiero enseñarte a los niños corriendo tras las hormigas voladoras que salen cuando llueve". Como despedida, Lacuesta añade un montaje que preparó para su encuentro en el Cinergies y que ahora cobra 
pleno sentido: "Como canción de despedida, también quiero enviarte una película antigua del director Segundo de Chomón. He editado la película con música de tus amigos, los Pascals, tocando una canción de mi querido Pascal Comelade". El montaje de Kiriki, Japanese acrobats (1907) con la música de The Skatalan logicofobism interpretada por Pascals (2001) confirma la intersubjetividad alcanzada por la correspondencia fílmica cuando esta abandona su simulación.

\section{Guerin y Mekas (2009-2011). De la intersubjetividad como imposibilidad y la correspondencia como antítesis}

Una vez más, la correspondencia comienza tras dos encuentros entre ambos cineastas. Para iniciarla, Guerin hace una concesión en favor de la fluidez de la comunicación y, por primera vez en su obra, expone su voz en la enunciación de las misivas, como "única elección natural para hacer la carta, con la voz, pensando en Jonas" (Tourneur, 2014: 4). El cineasta mantiene sin embargo la imagen en $\mathrm{B} / \mathrm{N}$ con la que viene trabajando en sus obras anteriores: Unas fotos en la ciudad de Sylvia (2007) y Guest (2010). Desde su primera misiva va a establecer la naturaleza de su dispositivo epistolar. La voz off, totalmente separada de la imagen visual, sitúa las imágenes, y su montaje, en un pasado que la voz comenta desde el presente de su enunciación (a excepción de la primera misiva). Sin embargo, descarta la intimidad y cercanía de lo que Chion denomina voz-yo acusmática (2004: 59), habitual en la enunciación epistolar, para alejarse de esa subjetividad mediante el tratamiento de la misma: una calidad de grabación que objetiviza al remitente. Así, el cineasta narra y reflexiona sobre una imagen visual ya construida. La correspondencia, que coincide con la última etapa de producción de Guest, se genera igualmente como narraciones de la experiencia del viaje. En su primera carta, desde Paris, Guerin toma la idea de los glimpses de Mekas para generar una imagen visual de la experiencia del flâneur, en realidad una estilización de esa experiencia, despojada de su sonido directo, mientras la voz off relata su situación actual y recuerda las palabras de Mekas en su primer encuentro: "I react to life": "No se reacciona a la vida como un flâneur a principios del siglo XXI. Un paseante actual procede con la conciencia de ser un paseante (Català, 2017: 76). La carta concluye con las imágenes prometidas al inicio: las de la puerta giratoria de la cafetería en la que se encuentra. Imágenes de nuevo cuidadosamente construidas y editadas, velando por el ritmo y el movimiento de las mismas, sin sonido directo.

La respuesta de Mekas, y el resto de sus misivas, se genera en la antítesis de la propuesta de Guerin, y en absoluta consonancia con el trabajo del cineasta. Sus cartas van a contener el mismo trabajo de su filmación diarística, que en esta ocasión será generosamente ofrecida al interlocutor epistolar: la filmación con sonido directo, incluida la voz del cineasta, la casi inexistencia del montaje, la ausencia de reflexión, la filmación cámara en mano y la autofilmación. La imagen del exterior del apartamento de Mekas, protagonizada por un árbol, acompaña la declaración de intenciones epistolares del autor, que incluye ya la negación de la reflexión: "Intentaré ofrecerte algunas impresiones [glimpses] de mi vida desde que recibí tu carta. Comentabas algo sobre mis filmaciones como una reacción, reacciones a la vida que me rodea. Lo son y no lo son. Quién sabe, quién sabe... Obsesiones, reacciones, recuerdos, implicación en lo que está pasando ahora mismo delante de 
mí, o de ti, mientras filmo". Tras esta definición del grado cero de su escritura epistolar, Mekas ofrece su trabajo habitual de filmación en esos días. La conclusión de la misiva reivindica su naturaleza diarística: Mekas vuelve a retratar el mismo árbol, ahora nevado. Además, muestra los límites del montaje en su práctica fílmica: asocia una imagen sonora de una conversación a una imagen visual del interior y sobreimpresiona un primer plano de sí mismo para despedirse: "Así es como transcurre mi vida".

La segunda misiva de Guerin es un nuevo enfrentamiento entre dos concepciones casi opuestas de la actividad fílmica, que muestran sus extremas diferencias, pero que en ningún caso pueden reducirlas. Así, la misiva recibida de Mekas se convierte en motivo marginal de la respuesta. Guerin relata su viaje a Harvard y su visita al Walden Pound: "Estos viajes de ida y vuelta de una imagen que se sucede con la anterior parece ser una forma de decir: he recibido tu carta, la he visto y leído, e incluyo algo visual de ella en mi respuesta" (Balló, 2014: 317). La voz epistolar comenta nuevamente unas imágenes que se despojan de su sonido directo, y que solo lo recuperan cuando el remitente abandona su enunciación; otro modo de separar la enunciación epistolar presente de la narración, pasada, de las imágenes. El cineasta nunca se dirigirá a Mekas en el sonido directo de las imágenes.

La respuesta de Mekas, su segunda carta, parece estar realizada sin visionar la anterior de Guerin, ya que el cineasta hará referencia al Walden Pound en su siguiente misiva. Así, se produce una clara revelación: su carta gana espontaneidad e interés cuando se libera de las obligaciones de la respuesta, de la referencia, de la intersubjetividad. Tras mostrar otro árbol ahora en flor, ya es primavera, su carta atesora un valioso instante vital en el que Mekas muestra a su interlocutor su sala de montaje y su trabajo para su próximo film, que se compondrá de las tomas descartadas de sus películas en 8mm: Out-Takes from the Life of a Happy Man (2012). Una emotiva secuencia que carece de montaje, solamente el generado por los cortes de grabación que necesita hacer Mekas para manejar la cámara y el dispositivo de edición de $8 \mathrm{~mm}$. El cineasta crea así una admirable muestra de ese grado cero de la escritura epistolar audiovisual, despojada de toda manipulación posterior, y reducida a la esencialidad de la imagen y el sonido presentes. Una suerte de lettre vérité, donde la inmediatez presente recoge los vestigios fílmicos de toda una existencia y la reacción del autor ante ellas: imágenes gastadas, y descartadas; recuerdos marginales y marginados que no merecieron, hasta este momento, la presencia cinematográfica: "Esta es la vida de un cineasta [...] Esta es mi vida en este planeta". Para despedirse, Mekas retoma la imagen primaveral de los árboles, la fuerza y vitalidad del instante presente.

La respuesta de Guerin es la máxima revelación de la imposibilidad de intersubjetividad. Escuchamos su voz sobre la imagen en negro: "Querido Jonas Mekas: En esta nueva entrega quiero retomar el esquema de tu carta precedente. A saber, una confrontación entre dos ventanas. Una primera ventana de un lado que da a un exterior de primavera; y otra, en el interior, que daría a imágenes de invierno". El trabajo espontáneo y no reflexivo de Mekas se convierte en inspiración para Guerin "confrontando dos ventanas que le han acompañado sin duda durante mucho tiempo sin que hasta ese momento se haya decido a teorizarlas, a asimilarlas a su particular reflexión epistolar" (Català, 2017: 77). La también primavera exterior de los árboles en flor se confronta con sus propias imágenes de invierno de la mesa de edición, en este caso digital: el encuentro con la joven cinéfila Nika Bohinc, convertido en ho- 
menaje póstumo. Se produce de nuevo la comparación antitética: frente a la mesa de edición analógica, a través de cuya ventanilla veíamos fotogramas de diferentes tomas descartadas, sin ningún orden ni preparación, Guerin ofrece el acabado montaje de ese encuentro pasado, convertido además en narración epistolar. Una vez más, el tiempo de la enunciación se va alternando con el tiempo de la narración, definidos por la ausencia y presencia, respectivamente, del sonido directo.

La siguiente misiva de Mekas se inicia con la autofilmación de este aludiendo a la segunda carta de Guerin, y de nuevo se omite la referencia a la carta anterior (la tercera): "Querido José Luis: My friend in cinema. He visto que has hecho un viaje maravilloso a Walden. Me hubiera gustado estar allí contigo. Pero tu has ido al nuevo mundo y yo, por error, he ido al viejo". Las imágenes del horror -primero en el antiguo cementerio judío en Cracovia y después en las salas de tortura del castillo de Banská Stiavnica, en Eslovaquia-, el error de visitar estos lugares, como dice Mekas, se convierten en metáfora del error epistolar: el de intentar forzar la mirada intersubjetiva, llevar la subjetividad a espacios que le son inalcanzables. En el caso de Mekas, el espacio de la reflexión. Tras las imágenes del viaje, una nueva autofilmación va a dar testimonio de este error (Imagen 11):

La verdad es que lo único que hago es filmar [...] Momentos de la vida que me rodea, amigos, mi propia vida, detalles, que tengo la necesidad de grabar, por alguna razón que desconozco y que me empuja a hacerlo [...] Después, la gente me pregunta por qué lo hago y qué sentido tiene. Entonces trato de racionalizarlo. Pero solo es un juego, un juego de palabras.

Frente a la desnuda declaración de Mekas, Guerin afronta esa misma exposición sobre la irrenunciable esencia reflexiva de la suya mediante una construcción audiovisual que se sitúa en las antípodas de su interlocutor. El cineasta muestra un plano fijo de un entorno urbano que encuadra a su vez una pantalla cinematográfica, con el que ofrece una explicación de su trabajo, definido por la reflexión sobre la estructura:

necesito imponerme unos límites, o unas restricciones. Ante todo, los propios límites del encuadre, que para mí es como un margen rígido, como una restricción. Como también es restricción la renuncia expresa de sonido y de color [...] Sin una cierta adversidad técnica no acabo de encontrar mi forma de filmar [...] Y necesito además elegir, tomar algunas elecciones.

La misiva concluye con un autorretrato que define su actividad cinematográfica: su imagen se refleja en la pupila de la mujer a la que filma (Imagen 12). La intersubjetividad se revela nuevamente como imposibilidad, lo que Steven Marsh analiza como "incompatibilidades aporéticas" (2013: 28), para generar una suerte de correspondencia antitética entre los dos autorretratos: su materialización más simple y espontánea (ese grado cero de la escritura epistolar audiovisual) y su máxima construcción reflexiva. Así, la correspondencia se convierte en reivindicación de las subjetividades de ambos cineastas frente a la amenaza del intento intersubjetivo: "la relevancia de la intersubjetividad en la filosofía contemporánea [...] refrenda bien la destitución bien la desaparición del sujeto (Thomas-Fogiel, 2014: 375). 

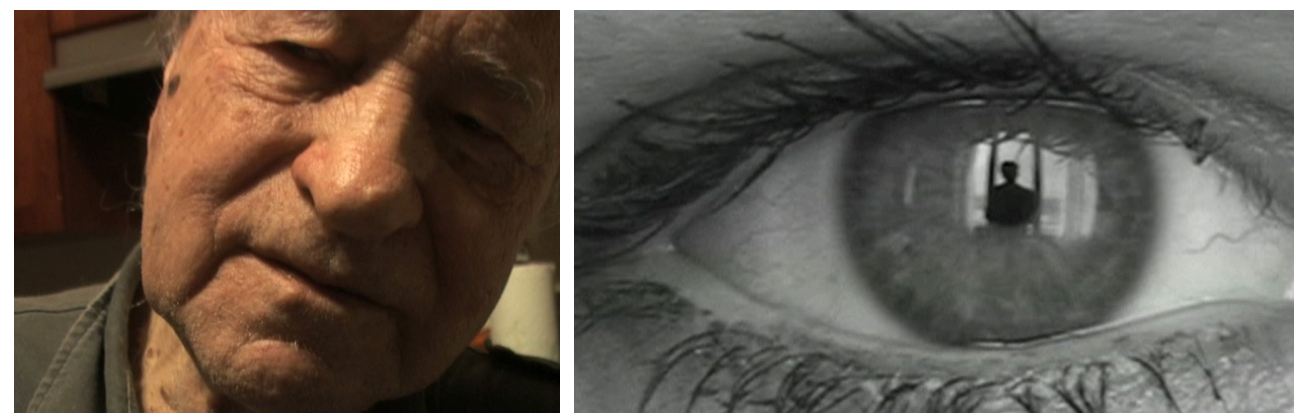

Imágenes 11 y 12. Correspondencia de José Luis Guerin y Jonas Mekas (2011).

Fuente: Captura de pantalla.

La última misiva de Mekas, de nuevo, no hace alusión a la carta de Guerin, y simplemente retoma la naturaleza de su actividad fílmica, su espontaneidad, su impulso irreflexivo, su ausencia de manipulación. No por casualidad, es su misiva más larga, quizá donde se permite al fin dejarse llevar olvidando las obligaciones de la tarea epistolar, sin dirigirse explícitamente a Guerin en ningún momento. Para la despedida, simplemente retoma el elemento inicial de su primera carta, el árbol frente a su ventana, un año después, de nuevo en compañía de la música, enfatizando así, una vez más, el carácter diarístico de sus misivas. Frente a la espontaneidad y simplicidad de esta conclusión, Guerin crea una última carta que pretende ser una "glosa de su figura", un homenaje a Mekas en la que se describe una misiva fallida, que debía construirse a partir de un plano de Mekas andando que Guerin grabara durante su segundo encuentro. En su lugar, el cineasta le envía las imágenes de un viaje pasado a Japón que concluye con la visita a la tumba de Yasujurō Ozu. Allí, unas hormigas trabajan con perseverancia para conseguir elevar una carga a través de la pared de piedra. Tras varios intentos, finalmente lo consiguen. Esta imagen podría ser metáfora también de la correspondencia fílmica, donde la única forma de alcanzar el objetivo, a saber, que la significación surja del intercambio, requiere de un esfuerzo conjunto que, en este caso, no lleva a la experiencia intersubjetiva sino a la confirmación de su imposibilidad. La correspondencia se convierte entonces en la reivindicación subjetiva ofrecida al destinatario, a partir de la cual surgen interesantes reflexiones acerca de la relación entre realidad e imagen (Brenez, 2011), o del intercambio estético como acto de imaginación política (Fibla, 2014). Esta antítesis se confirma si observamos los films-carta de cada uno de ellos. Con Letters to Friends... from Nowhere... Video Letter \#1 (1997), Letters from Nowhere N.1 (1997) y A Letter from Greenpoint (2005) Mekas mostraba igualmente las experiencias emocionales del día a día, sin la existencia de un destinatario explícito. Es interesante indicar que estas formas epistolares están asociadas también al paso del formato analógico al digital. Por el contrario, Dos cartas a Ana (2011), de Guerin, se construye como un magnífico film-ensayo sobre la creación artística y la relación entre sus diferentes disciplinas (Monterrubio, 2019a). 


\section{Life May Be (2014) de Mark Cousins y Mania Akbari. La intersubjetividad como resultado}

El film se construye como una correspondencia entre ambos cineastas, tres misivas de Cousins y dos de Akbari, en la que es protagónica la cuestión de la identidad cultural y su vínculo con la creación artística. Como la mayor parte de la obra audiovisual de Cousins, su escritura epistolar se concibe desde la práctica ensayística. Su primera misiva genera un interesante dispositivo de enunciación. Un plano subjetivo avanza por una senda de un bosque escocés y la voz off del cineasta explica la naturaleza epistolar del film. La cámara se detiene entonces par encuadrar un magnífico paisaje que se mantendrá a lo largo de toda la misiva y que sin duda evoca Stemple Pass (James Benning, 2012). El cineasta narra entonces cómo le propusieron realizar una reseña sobre One. Two. One (Yek. Do. Yek, Mania Akbari, 2011) para la edición en DVD de la película, y él escribió entonces una carta dirigida a la cineasta que ahora se dispone a releer. Es decir, la misiva audiovisual incluye una misiva literaria anterior; una suerte de mise en abyme epistolar. La imagen del paisaje (y su tenue sonido directo) y la voz de Cousins dan paso a una segunda situación de enunciación, un bar de Edimburgo, que será igualmente referenciado en la misiva literaria. A esta confluencia de coordenadas espacio-temporales se añadirán a continuación otras imaginadas por el remitente. Cousins reflexiona sobre la obra de Akbari, sus dos largometrajes, 20 Fingers (2004), que supone para Cousins una revelación, y One. Two. One, a partir de cuya estructura en secuencias el cineasta propone a la destinataria diferentes viajes imaginados, en torno a las creaciones artísticas con las que Cousins relaciona la obra de Akbari. A Estocolmo, para descubrir la relación de la obra de la creadora iraní con Persona (Ingmar Bergaman, 1966). A Roma, donde comparar los cuadros de la sacra conversazione con una secuencia de diálogo de One. Two. One. A Teherán, donde se conocieron y visitaron la tumba de Forough Farrokhzad, escritora admirada por Cousins y de la que cree que Akbari es digna sucesora. A Hungría, para encontrarse con otros maestros del plano secuencia, como Béla Tarr. Y finalmente a Londres, donde reside actualmente Akbari, para realizar una emocionante comparación con Virginia Woolf e imaginar el final del viaje: "Acabemos el viaje juntos en la puerta de la antigua residencia de Virginia [...] Hagamos una foto de ti allí con nuestros teléfonos y veamos en ella la imagen de una gran artista [...] Me gusta viajar contigo, Mania". Concluida la lectura de la misiva pasada, Cousins se despide en la presente: "Esa era la carta, Mania. Es extraño releerla aquí, en estas montañas escocesas. Resulta que la leíste. ¿Cómo lo sé? Por esta foto” El paisaje escocés da paso a una foto de Akbari en la puerta de la residencia de Woolf, para concluir la misiva (Imagen 13). La confrontación entre las temporalidades pasadas e imaginadas por Cousins y el plano fijo del paisaje, que se va transformando con el movimiento de la niebla, ofrece una experiencia espacio-temporal del acto epistolar, la relectura en este caso, donde un poderoso aquí y ahora cohabita con experiencias pasadas e imaginadas y, más concretamente, con sus ausentes imágenes, hasta materializarse la última de ellas a través de la intersubjetividad.

Akbari va a retomar el viaje imaginario trazado por Cousins para ofrecer uno vivenciado, el de su exilio. A la imagen estática del paisaje de su corresponsal, Akbari opone una misiva construida casi en su totalidad con imágenes fijas, sobre la que su voz off vuelve a ser predominante. La misiva se inicia con imágenes del 
paisaje de Meygun (de la casa familiar de Akbari), sobre el que escuchamos el inicio del poema Born again (1981) de Forough Farrokhzad, de donde el film toma su título. A continuación, Akbari describe la vida familiar antes de iniciar el relato del viaje: Dubai, Estocolmo, Londres. Las imágenes ilustran lo narrado, y las palabras reflexionan sobre las imágenes mostradas. Las de Dubai, acompañadas de una canción de Souad Massi, Raoui (2001) retratan la contradicción entre la imagen de la mujer occidental asociada a la publicidad y la situación de la mujer en el país. Akbari reflexiona sobre la falta de libertad: "Más allá de la fachada, el vacío es infinito. No hay libertad, no hay democracia [...] no hay diferencia entre las mujeres que son obligadas por la sociedad para perseguir la belleza a cualquier precio, y las mujeres que son obligadas a llevar el chador. Ambas situaciones son insoportables". En Suecia. Akbari opone las antiguas imágenes familiares con las imágenes pictóricas de los museos visitados, varias de ellas en torno al retrato femenino y el desnudo, y las acompaña con la canción Million scarlet roses (Alla Pugacheva, 1982). La experiencia como mujer se vincula entonces a la experiencia del exilio: "La profunda conciencia de que algo nos persigue. [...] A menudo buscamos la alegría en las cosas triviales de la vida y descubrimos que solo el arte puede unirnos a las raíces vitales de la existencia”. En Londres, con la música de Sophie Hunger, Train People (1983), Akbari retoma las imágenes de los escaparates, semejantes a los retratados en Dubai. Fijada su residencia en esta ciudad, la cineasta invita a Cousins a encontrarse, surgiendo entonces la imagen en movimiento, con su sonido directo, de la propia Akbari en su nuevo hogar, haciendo tareas cotidianas: "Pienso en lo que me ha pasado y en lo que me va a pasar". La cineasta retoma entonces las imágenes fijas para mostrar la mudanza de sus pertenencias que viajarán desdeTeherán hasta Londres. Objetos que conforman la materialización de su existencia, y que invita nuevamente a Cousins a desempaquetar juntos cuando lleguen: "Mark, estas cajas estarán esperando tus manos y las mías para revelar sus secretos, hacer desaparecer su polvo, y colocarlas sobre estanterías nuevas". Akbari añade que le gustará llevarle a la casa de Ibrahim Golestan, productor de The House is Black (1962), la única película realizada por Farrokhzad: "La película realizada por la mujer cuyo nombre tienes tatuado en el brazo". Una imagen fija nos permite contemplar a ambos cineastas juntos, en la que Akbari muestra a cámara el tatuaje de Cousins, de signo muy diferente al que contemplaremos más tarde en el cuerpo de Akbari. A continuación, sobre la imagen en negro, continúa el poema de Farroukhzad con el que se iniciara la misiva para concluirla ahora.

Si la primera carta de Cousins era una experiencia audiovisual de la relectura epistolar, la segunda lo es de su escritura. La misiva se inicia con un plano fijo de un sofá vacío en el que entra en cuadro el cineasta para tumbarse en él con el ordenador. Mientras teclea, escuchamos su voz off. La imagen va a mostrar, por tanto, la temporalidad y la atmósfera de la escritura literaria epistolar. Tras visionar la misiva de Akbari el día anterior, Cousins le escribe ahora desde un hotel en Kaunas, Lituania, para reflexionar sobre lo expuesto por Akbari en torno a los cuerpos, el desnudo y el vacío existencial. Sobre el mismo encuadre se producen cortes de plano con el que se incide en la temporalidad de la escritura, mientras el cineasta bebe cerveza, come patatas fritas, y se detiene a pensar. Su reflexión sobre el cuerpo y el desnudo va a incluir otras imágenes que se intercalan. La narración de las experiencias personales y reflexiones de Cousins acerca del desnudo 
se materializan también en imagen: los cortes muestran al remitente primero sin pantalones y luego desnudo mientras continúa escribiendo. Tras relatar una experiencia personal en torno a la vertiente política del desnudo, la misiva continúa con el cineasta ya sin escribir, meditativo. Se produce entonces un brusco salto de la misiva a la postal audiovisual: "Aquí hay cien lugares en los que he estado recientemente". Cien postales audiovisuales, de apenas uno o dos segundos, cada una con su sonido directo, se van sucediendo por simple corte, exponiendo así sus diferencias respecto a la misiva. Al concluir este montaje de postales, la imagen epistolar muestra ahora al cineasta dormido mientras su voz relata, y la imagen muestra, los lugares visitados en Kaunas. Cousins le hace entonces una pregunta a su interlocutora: “¿Los objetos de tu mudanza podrán llenar el vacío del exilio?”. La última imagen recupera la situación de enunciación para mostrar el sofá ya vacío: "Gracias por escuchar mis divagaciones. Mark".

La respuesta de Akbari retoma lo expuesto por su corresponsal, para crear un autorretrato del desnudo que en su caso está irremediablemente vinculado a la maternidad y el cáncer padecido, narrado en su documental 10 + 4 (Dah be alaveh chahar) (2007), film concebido como la continuación de Ten (Abbas Kiarostami, 2002) en el que Akbari era la protagonista. Su voz off se acompaña ahora de la imagen de video, con la que mostrará su cuerpo: "Estoy de acuerdo con tus opiniones sobre el cuerpo". Las imágenes de Akbari tomando un baño se alternan con diferentes imágenes fijas. En primer lugar, tres miniaturas iraníes con las que Akbari reflexiona sobre el significado del desnudo en su cultura: "En mi cultura, el desnudo es el final del camino [...] En tu cultura, el cuerpo es solo el comienzo, un punto de partida". Después, imágenes de mujeres iraníes cubiertas, rezando. A continuación, dos imágenes de la propia Akbari bañándose en el mar, igualmente cubierta: "Desde la infancia me han enseñado que mi cuerpo es una molestia; que debía cubrirlo". Finalmente, imágenes de mezquitas con las que la cineasta reflexiona sobre la sensualidad de sus arquitecturas. Y todas ellas, enfrentadas al cuerpo de Akbari desnudo, sumergido en el agua o emergido de ella: "La voz de mi cuerpo es la voz de la culpa". El agua cubre el torso de Akbari que esta lava con sus manos, velando y desvelando la doble mastectomía sufrida: "Perdí parte de mi cuerpo. Fue como cruzar una frontera y dejar algo atrás. Me vi obligada a sacrificar parte de mi cuerpo para salvarlo, para salvar mi vida". La cineasta muestra una nueva cicatriz de su cuerpo, la de una cesárea, cubierta por un tatuaje: "Mi cuerpo cambia constantemente". A continuación, la imagen de la bañera vaciándose de agua se convierte en poderosa metáfora del vacío del que habla Akbari: "Mark, no sé quién soy, ¿tú sabes quién eres? La cineasta concluye su carta con una última imagen en la que se materializa la intersubjetividad alcanzada a través de la correspondencia fílmica (Imagen 14):

Escribí mi cuerpo para ti, Mark. Me estoy preparado para volver a la casa de Virginia Woolf y hacerme una fotografía en la misma posición. Nunca me he hecho una fotografía desnuda. No sé qué aspecto tendrá mi cuerpo. Escribí la novela Orlando de Virginia Woolf en farsi sobre mi cuerpo. Un cuerpo que tiene muchas historias propias. Si mi cuerpo pudiera hablar, deberíamos gritar. Me coloqué delante de su casa en la misma posición e hice esta foto para ti y para todo el mundo. 

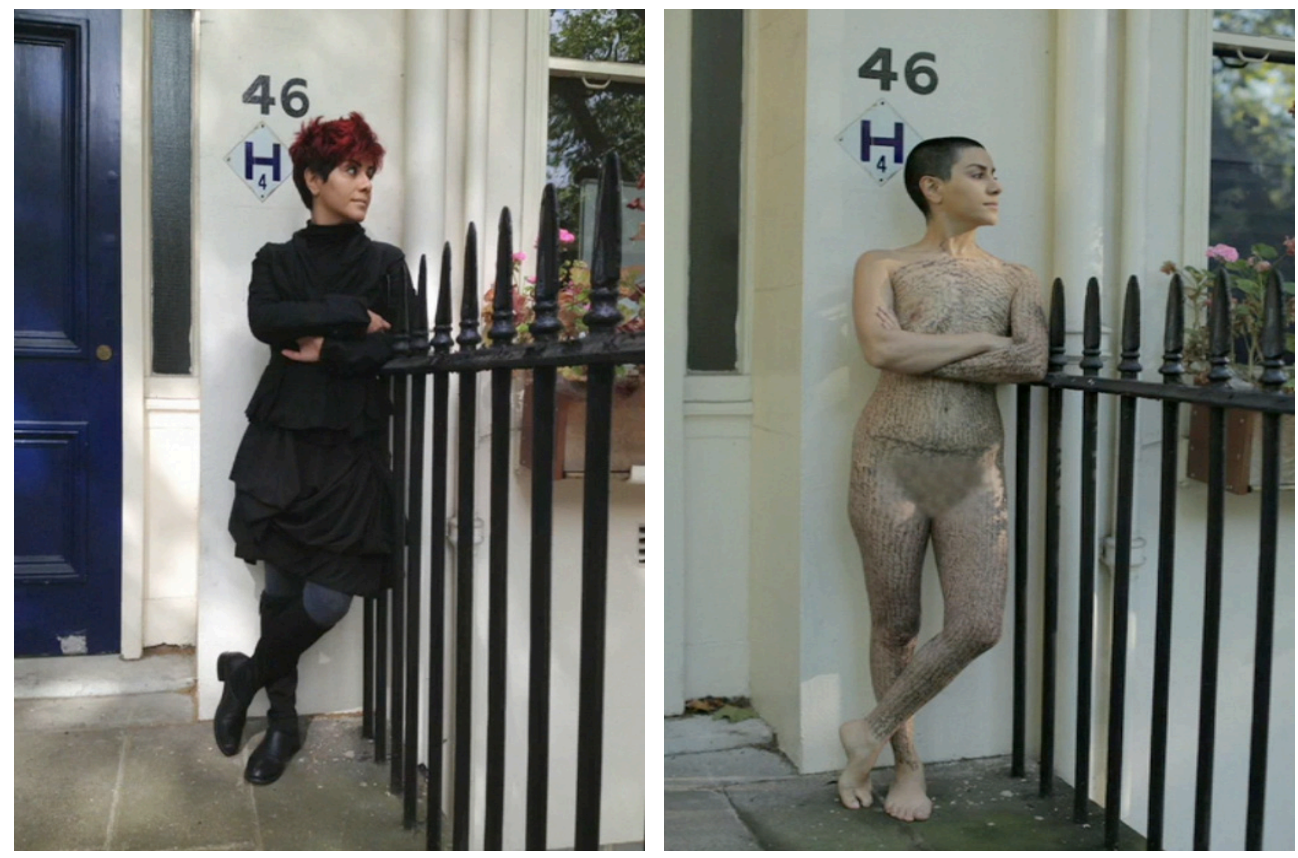

Imágenes 13 y 14. Life May Be (Mark Cousins y Mania Akbari, 2014). Fuente: Captura de pantalla.

Esta potente imagen es el exitoso resultado intersubjetivo del intenso, profundo e íntimo intercambio epistolar, que se materializa aquí en la creación y transformación de una imagen. La sensibilidad artística de Cousins genera la idea de una fotografía que conectaría a dos creadoras cuyas respectivas obras representan para él dos imprescindibles cumbres de la cultura inglesa e iraní. Akbari crea entonces esa imagen para verter sobre ella la intersubjetividad que continúa fraguándose entre los corresponsales. La discusión en torno al significado de la desnudez en ambas culturas, y para ambos cineastas en sus respectivas biografías, transforma la imagen para añadirle la profundidad intersubjetiva que ambos cineastas han alcanzado. El cuerpo desnudo de Akbari, testimonio de diferentes mutaciones, se transforma en reivindicación feminista sobre su pasado y su presente y trasciende las fronteras culturales: el texto de Orlando (1928) traducido al farsí, escrito sobre la piel de Akbari, simboliza la lucha de las mujeres en todos los ámbitos de su existencia.

\section{Conclusiones}

Tras todo lo expuesto, es posible extraer diversas conclusiones sobre esta práctica fílmica. En primer lugar, su naturaleza audio-visual y las múltiples posibilidades de su materialización, frente a las que los corresponsales realizan diversas elecciones, provoca que su realización no pueda evitar diversos elementos que surgen con diferente relevancia. En primer lugar, la construcción de la correspondencia implica una reflexión acerca de la misma, del conjunto de elementos elegidos para conformarla. Parafraseando a Català (2019: 18), la correspondencia fílmica, en menor o mayor 
medida, se piensa a sí misma, reflexiona sobre su forma de corresponder. En segundo lugar, la correspondencia conlleva igualmente, en diferentes grados, la materialización de la atmósfera anímica y emocional que se crea entre los corresponsales. Finalmente, como hemos intentado demostrar, la correspondencia se define por un intento de intersubjetividad que se materializa en diferentes acciones-reacciones y emociones-reflexiones. Podríamos describir entonces la práctica de la correspondencia fílmica como un espectro, definido por tres ejes, que comprende infinitas posibilidades. El primero, referido a la forma, tendría como extremos lo que hemos denominado el grado cero de la escritura epistolar audiovisual, que prescinde del montaje -las prácticas de Mekas, y Kramer y Dwoskin en sus primeras cartas- y la máxima construcción de la misiva: montaje de imagen y sonido, no sincrónicos, con las que se conforman diferentes niveles y temporalidades de enunciación y narración -las prácticas de Guerin y Lacuesta-. El segundo, referido a la expresión subjetiva, tendría como extremos la expresión de la emoción -las misivas de Kawase en su primera correspondencia- y la expresión reflexiva-Tanikawa y Terayama hacen de su correspondencia un film-ensayo en torno al sentido y la identidad-. El tercero, sobre el que hemos centrado nuestro análisis, representaría el grado de materialización de la intersubjetividad. A continuación, intentamos exponer las conclusiones alcanzadas a través de la descripción de este eje.

En uno de sus extremos, grado cero de intersubjetividad, y como indicábamos en la introducción, se situarían los envíos que, si bien responden al intercambio, no interpelan en ningún caso al tú epistolar. Las obras analizadas, que sí abordan esta compleja tarea, generan tentativas y hallan resultados diversos, todos ellos de gran interés. En primer lugar, la intersubjetividad se puede evidenciar como imposibilidad cuando la actividad fílmica de los corresponsales se revela como antitética. La correspondencia de Guerin y Mekas constatan esta imposibilidad, con dos resultados diferentes: Guerin puede instrumentalizar las misivas diarísticas, espontáneas e impulsivas de Mekas como inspiración de sus reflexiones, mientras que en sentido contrario sus misivas reflexivas suponen para Mekas una propuesta de intersubjetividad que amenaza su subjetividad. Mientras que la reflexión puede inspirarse en la espontaneidad, esta se siente paralizada frente a la anterior. En segundo lugar, la intersubjetividad puede abordarse como juego creativo, como simulacro fílmico. La correspondencia entre Lacuesta y Kawase, debido a una excesiva definición a priori del intercambio, simula la intersubjetividad en las cuatro primeras misivas con dos objetivos diferentes: la ficcionalización autobiográfica en el caso de Lacuesta y la experiencia de la intimidad documental en el de Kawase. Solo tras la interacción real y la desaparición de las premisas, su correspondencia accede entonces a una verdadera intersubjetividad, que asimila la subjetividad del otro en su propia expresión. Así, Lacuesta accede al universo documental e íntimo de Kawase mientras esta se adentra en el universo fabulador de aquel. En tercer lugar, la intersubjetividad puede convertirse en dialéctica de la correspondencia fílmica. Partiendo de dos actividades cinematográficas muy diferentes -como en el caso de Guerin y Mekas-, Kawase y Kore-eda generan una dialéctica acerca de cómo alcanzar la intersubjetividad desde esas diferencias: la imagen-emoción de Kawase y la imagen-documento de Koreeda. Ambos cineastas, en mayor medida en el caso de Kore-eda, logran movilizar su mirada para asimilar la del otro. En cuarto lugar, la correspondencia fílmica surge de la búsqueda de la intersubjetividad; rechazando cualquier acuerdo previo, afrontando un espacio desconocido y generando así una de las expresiones de mayor 
vulnerabilidad. La correspondencia de Erice y Kiarostami materializa esa búsqueda en el espacio de su creación cinematográfica: las diferentes propuestas, los caminos abandonados y las sendas elegidas, las dudas y los temores, las esperas e incluso las decepciones, hasta lograr compartir sus miradas. En quinto lugar, la intersubjetividad surge como resultado de la correspondencia. Cousins y Akbari desarrollan un intercambio epistolar que surge del interés del primero por la obra de la segunda. El conocimiento mutuo que se produce a través de la correspondencia logra finalmente una intersubjetividad que se materializa en una imagen que contiene la mirada de ambos. Finalmente, la intersubjetividad se constituye como punto de partida de un deseo de reflexión compartida. Tanikawa y Terayama convierten su correspondencia en un film-ensayo que genera su reflexión filosófica, su pensamiento cinematográfico, precisamente a través de la intersubjetividad materializada en forma de diálogo. Kramer y Dwoskin desean compartir sus universos emocionales y existenciales a fin de reflexionar sobre su condición de cineastas americanos exiliados en Europa. La correspondencia se construye entonces como una serie de dípticos que abordan las mismas cuestiones y donde sus espacios íntimos y sus digresiones van encontrando múltiples resonancias, puntos de encuentro y también reveladoras divergencias. Su correspondencia se convierte en una suerte dimensión emocional y existencial intersubjetiva. El desplazamiento de la subjetividad a la intersubjetividad que posibilita la correspondencia fílmica es un fenómeno tan complejo como atractivo, cuyos resultados, como hemos expuesto, son múltiples y ofrecen interesantes reflexiones acerca del audiovisual contemporáneo.

\section{Bibliografía}

Arroyo, Sergio Raul. (2011). "La genealogía de las cartas". En Jordi Balló (dir.), Todas las cartas. Correspondencias filmicas. Barcelona: CCCB / Intermedio, 238-248.

Balló, Jordi. (2006). "Noticia de un proceso". En Jordi Balló (dir.), Erice - Kiarostami. Correspondencias. Barcelona: CCCB, 74-81.

Balló, Jordi. (dir.) (2011). Todas las cartas. Correspondencias filmicas. Barcelona: CCCB / Intermedio.

Balló, Jordi. (2012). "L'estratègia del desplaçament". Comunicació: Revista de Recerca i d'Anàlisi, 29(1), 9-23. Recuperado de https://www.raco.cat/index.php/Comunicacio/article/view/264284

Balló, Jordi. (2014). "Las correspondencias como herencia literaria aplicada al cine". En Brice Castanon-Akrami; Françoise Heitz; Emmanuel Le Vagueresse; Catherine OrsiniSaillet (eds.) Littérature et cinema. Allers-retours. Bruxelles: Orbis Tertius, 313-321.

Balló, Jordi y Pintor, Iván. (2014). "Exhibition cinema. "A Crossroads between the Cinema and the Museum in Contemporary Spanish Filmmaking". Hispanic Research Journal, 15(1), 35-48. https://doi.org/10.1179/1468273713Z.00000000072

Bax, Dominique (ed.). (2006). Robert Kramer. Bobgny: Le Magic Cinéma.

Bellour, Raymond. (2009). Entre imágenes. Foto. Cine. Video. Buenos Aires: Colihue.

Bergala, Alain. (2011). Te escribo estas imágenes...”. En Jordi Balló (dir.) Todas las cartas. Correspondencias filmicas. Barcelona: CCCB / Intermedio, 20-36

Bovier, François. (2006) "Entretien avec Stephen Dwoskin: filmographie commentée par l'auteur": Décadrages $n^{\circ} 7$. Recuperado de https://www.decadrages.ch/stephen-dwoskinn-7-printemps-2006 
Brenez, Nicole. (2011). “Mímesis 2”. En Jordi Balló (dir.), Todas las cartas. Correspondencias filmicas. Barcelona: CCCB / Intermedio, 90-115

Chion, Michel. (2004). La voz en el cine. Madrid: Cátedra.

Català, Josep Maria. (2014). Estética del ensayo. La forma ensayo, de Montaigne a Godard. Valencia: Universidad de Valencia.

Català, Josep Maria. (2017). "El hombre que mira. Alegorías del espíritu: imagen, ensayo y subjetividad (El cine de José Luis Guerin)". En Jesús Rodrigo (ed.), Unas sombras, un tren. Shangrila, 28-29, pp. 48-95.

Català, Josep Maria. (2019). "Pensar el cine de pensamiento. Ensayos audiovisuales, formas de una razón compleja". En Norberto Mínguez (ed.), Itinerarios y formas del ensayo audiovisual. Barcelona: Gedisa, 13-59.

Dwoskin, Stephen y Kramer, Keja Ho. (2006) Rouge. Recuperado de http://www.rouge.com. au/9/eyes.html (Fecha de acceso: 30/08/2019)

Faulkner, William. (1983). Luz de agosto. Barcelona: Seix Barral.

Fibla, Enrique. (2014). "Cine epistolar: imaginación y política del intercambio estético". Kamchatka, 3, 207-226. Recuperado de https://ojs.uv.es/index.php/kamchatka/article/ view/3575

Jayyam, Omar. (1993). Robaiyyat. Madrid: Hiperión.

Kramer, Robert. (1997). Declaraciones realizadas en el XV Festival Internazionale Cinema Giovani de Turin. Recuperado de https://luxmovingimage.tumblr.com/post/76937324241/ video-letters-stephen-dwoskin-robert-kramer

London. Barbara. (1990). "Video Letter by Shuntaro Tanikawa and Shuji Terayama An Introduction" in Camera Obscura, 8,3(24), 195-203.

Marsh, Steven. (2013). "Turns and Returns, Envois/Renvois: The Postal Effect in Recent Spanish Filmmaking”. Discourse: Journal for Theoretical Studies in Media and Culture, 35(1), 24-45. Recuperado de https://digitalcommons.wayne.edu/discourse/vol35/iss1/2/

Monterrubio, Lourdes, (2016). "From militant cinema to essay film. Letter to Jane by JeanLuc Godard and Jean- Pierre Gorin”. L'Atalante. Revista de estudios cinematográficos, 22, 55-66. Recuperado de http://www.revistaatalante.com/index.php?journal=atalante\&page $=$ article\&op $=$ view\&path $\% 5 \mathrm{~B} \% 5 \mathrm{D}=332$

Monterrubio, Lourdes, (2018a). De un cine epistolar. La presencia de la misiva en el cine francés moderno y contemporáneo. Santander: Shangrila Ediciones.

Monterrubio, Lourdes, (2018b). "Sobre los inicios del cine contemporáneo: Primer plano de Abbas Kiarostami y El sol del membrillo de Víctor Erice. La fraternidad documentalficción como síntesis entre el cine primitivo y la modernidad cinematográfica". L'Atalante. Revista de estudios cinematográficos, 25, 165-180. Recuperado de http://www.revistaatalante.com/index.php?journal=atalante\&page $=$ article\&op=view\&path $\% 5 \mathrm{~B} \% 5 \mathrm{D}=441$

Monterrubio, Lourdes, (2019a). "Dispositivos de enunciación del film-ensayo español contemporáneo. Evolución de la subjetividad ensayística y su pensamiento en acto". Studies in Spanish and Latin American Cinemas, 16(3), 335-361.

Monterrubio, Lourdes, (2019b). "La Morte Rouge (soliloquio) de Víctor Erice. Del trauma a la fraternidad: el intersticio entre realidad y ficción”. En Noberto Mínguez (ed.) Itinerarios y formas del ensayo audiovisual. Barcelona: Gedisa, 113-134.

Petrus, Anna. (2011). “In Between days. Pequeñas revelaciones de lo íntimo, lo efímero y lo invisible”. En Jordi Balló (dir.) Todas las cartas. Correspondencias filmicas. Barcelona: CCCB / Intermedio, 170-189.

Pintor, Iván. (2011). “Queridos Víctor y Abbas”. En Jordi Balló (dir.) Todas las cartas. Correspondencias filmicas. Barcelona: CCCB / Intermedio, 48-70 
Rancière, Jacques. (2011). El destino de las imágenes. Pontevedra: Politopías.

Rascaroli, Laura. (2017). How the Essay Film Thinks. Oxford: Oxford University Press.

Rilke, Rainer María. (2003). Los cuadernos de Malte Laurids Brigge. Madrid: Editorial Losada.

Tanikawa, Shuntarō. (2014). Dos millones de años luz de soledad. México D.F.: Universidad Autónoma Metropolitana.

Thomas-Fogiel, Isabelle. (2014). "L'intersubjectivite' : perspectives philosophiques et philosophie des perspectives". En Christiane Moro, Nathalie Muller Mirza et Pascal Roman (eds.). L'intersubjectivité en questions. Lausanne: Éditions Antipodes, 349-389.

Tourneur, Cécile. (2014). "La correspondance filmée de José Luis Guerin et Jonas Mekas : des voix en écoute". Entrelacs. Cinéma et audiovisuel, 11. Recuperado de http://entrelacs. revues.org/1486 